Research article

urn:lsid:zoobank.org:pub:67FB160D-14E1-4970-8190-4F927DDC4DC4

\title{
Three new and five known species of Diplopeltoides Gerlach, 1962 (Nematoda, Diplopeltoididae) from Sweden, and a revision of the genus
}

\author{
Oleksandr HOLOVACHOV ${ }^{1, *} \&$ Sven BOSTRÖM ${ }^{2}$ \\ 1,2 Department of Zoology, Swedish Museum of Natural History, \\ Box 50007, SE-104 05 Stockholm, Sweden. \\ *Corresponding author: oleksandr.holovachov@nrm.se \\ ${ }^{2}$ Email: sven.bostrom@nrm.se \\ ${ }^{1}$ urn:lsid:zoobank.org:author:89D30ED8-CFD2-42EF-B962-30A13F97D203 \\ ${ }^{2}$ urn:lsid:zoobank.org:author:528300CC-D0F0-4097-9631-6C5F75922799
}

\begin{abstract}
Eight species of Diplopeltoides are described from the Swedish west coast. Diplopeltoides suecicus sp. nov. has the cuticle with longitudinal striation visible only under SEM; cuticular plate underlying the cephalic cuticle around the amphid present; cephalic sensilla 4-6 $\mu \mathrm{m}$ long; amphid an inverted U-shape; wide space between amphidial branches areolated; spicules 27-31 $\mu \mathrm{m}$ long; gubernaculum with caudal apophysis. Diplopeltoides longicaudatus sp. nov. is characterized by a cuticle without longitudinal striation; cuticular plate underlying cephalic cuticle around amphid present; cephalic sensilla $13 \mu \mathrm{m}$ long; amphid an inverted U-shape; narrow space between amphidial branches not ornamented; spicules unequal in size, 27-31 $\mu \mathrm{m}$ long; gubernaculum absent; midventral precloacal cuticular ridge present. $D$. grandis sp. nov. is characterized by a cuticle with longitudinal striation; cuticular plate underlying cephalic cuticle around amphid present; cephalic sensilla $18.5 \mu \mathrm{m}$ long; amphid an inverted U-shape; wide space between amphidial branches punctate. The following taxonomic changes are proposed: Diplopeltoides asetosus (Juario, 1974) comb. nov., Diplopeltoides botulus (Wieser, 1959) comb. nov., Diplopeltoides bulbosus (Vitiello, 1972) comb. nov., Diplopeltoides lucanicus (Boucher \& Helléouët, 1977) comb. nov., Diplopeltoides pumilus (Vincx \& Gourbault, 1992) comb. nov. and Diplopeltoides striatus (Gerlach, 1956) comb. nov. Diplopeltoides holovachovi Fadeeva \& Mordukhovich, 2013 is synonymised with Diplopeltoides pumilus comb. nov. An updated key to the species of Diplopeltoides is provided.
\end{abstract}

Keywords. Identification key, morphology, SEM, taxonomy.

Holovachov O. \& Boström S. 2017. Three new and five known species of Diplopeltoides Gerlach, 1962 (Nematoda, Diplopeltoididae) from Sweden, and a revision of the genus. European Journal of Taxonomy 369: 1-35. https://doi.org/10.5852/ejt.2017.369 


\section{Introduction}

The genus Diplopeltoides was proposed by Gerlach (1962) for the species Diplopeltis ornatus Gerlach, 1950 with the main diagnostic characters: "complicated cuticular structure and a ring-shaped cephalic capsule". The original description was subsequently supplemented by Timm(1961) and Lorenzen (1981), who expanded the description with diagnostic characters of the digestive and the female reproductive systems. Tchesunov $(1990,2006)$ added three species to this genus: he described Diplopeltoides mastigia Tchesunov, 1990 as new to science and transferred Diplopeltula anatolii Voronov, 1982 and Diplopeltula nuda Gerlach, 1956 to Diplopeltoides. Another new species was added by Jensen (1991), who described Diplopeltoides linkei Jensen, 1991. One year later, yet another species, Diplopeltis onustus Wieser, 1956, was transferred to the genus Diplopeltoides by Vincx \& Gourbault (1992). However, this action was contested in a subsequent publication in which the taxonomy of the genus was completely revised (Holovachov et al. 2009). The authors also described three new species (Diplopeltoides axayacatli Holovachov, Tandingan De Ley, Mundo-Ocampo, Gingold \& De Ley, 2009, D. santaclarae Holovachov, Tandingan De Ley, Mundo-Ocampo, Gingold \& De Ley, 2009 and D. paramastigia Holovachov, Tandingan De Ley, Mundo-Ocampo, Gingold \& De Ley, 2009) and transferred Diplopeltula pulchra Vincx \& Gourbault, 1992 and Diplopeltula sundensis Jensen, 1978 to Diplopeltoides. Since then, one new species, Diplopeltoides holovachovi Fadeeva \& Mordukhovich, 2013 was proposed by Fadeeva \& Mordukhovich (2013), making a total of 11 species.

Eight species of the genus Diplopeltoides Gerlach, 1962 were found during ongoing studies of marine nematodes along the west coast of Sweden. Three species, D. suecicus sp. nov., D. longicaudatus sp. nov. and $D$. grandis sp. nov., are described as new to science. The remaining five species, namely D. asetosus (Juario, 1974) comb. nov., D. bulbosus (Vitiello, 1972) comb. nov., D. nudus (Gerlach, 1956) Tchesunov, 2006, D. pumilus (Vincx \& Gourbault, 1992) comb. nov. and D. linkei Jensen, 1991 are new to the fauna of Sweden.

Morphological data obtained from observations of these eight species provides grounds for the ongoing update of the taxonomy of the genus Diplopeltoides and a revision of the poorly defined genus Diplopeltula Gerlach, 1950, which implies the transfer of six known species from the genus Diplopeltula to the genus Diplopeltoides: D. botulus (Wieser, 1959) comb. nov., D. lucanicus (Boucher \& Helléouët, 1977) comb. nov., D. striatus (Gerlach, 1956) comb. nov. and three species mentioned above (D. asetosus, D. bulbosus and D. pumilus). Exclusion of these six species from Diplopeltula does not require any modifications to the diagnosis of this genus, recently published by Leduc (2017).

\section{Material and methods}

Bottom sediment samples were collected at several locations in the southern part of the Skagerrak and in the Gullmarn Fjord off the west coast of Sweden. All samples were collected with a bottom dredge or box corer and further sieved in the laboratory before fixation. Nematodes were extracted from samples using a decanting and sieving method (smallest mesh sizes: $45 \mu \mathrm{m}$ or $70 \mu \mathrm{m}$ ). Fresh water was used during sieving to induce an osmotic shock in nematodes inducing their detachment from the substrate. Samples were immediately fixed in a $4 \%$ formaldehyde solution in fresh water.

For light microscopy, formaldehyde-preserved specimens were transferred to pure glycerine using the rapid method of Seinhorst (1959) as modified by De Grisse (1969). Permanent nematode mounts on glass slides were prepared using the paraffin wax ring method. After measuring and observations, some specimens were removed from their slides and rehydrated by first gradually adding drops of S2 (5\% glycerine, $95 \%$ ethanol) to glycerine in an embryo-dish, starting with a 1:4 ratio of S2 to glycerine, until the volume tripled, then gradually adding distilled water until the volume tripled again. The specimens were then washed in distilled water before resuspension in formaldehyde. For SEM, specimens were 
post-fixed in $1 \%$ osmium tetroxide $\left(\mathrm{OsO}_{4}\right)$ and transferred to pure acetone through an acetone/distilled water series. Specimens were critical point dried in liquid $\mathrm{CO}_{2}$, mounted on stubs, gold-plated under vacuum to a thickness of $200 \AA$ in an Agar High Resolution Sputter Coater Model 20, and examined in a Hitachi S-4300 SEM at an accelerating voltage of $10 \mathrm{kV}$.

All curved structures were measured along the curved median line. Type and other specimens are deposited in the invertebrate collections of the Department of Zoology, Swedish Museum of Natural History, Stockholm, Sweden (SMNH). Abbreviations used in Tables are according to Hunt \& PalomaresRuis (2012).

\title{
Results
}

\author{
Phylum Nematoda Potts, 1932 \\ Class Chromadorea Inglis, 1983 \\ Order Plectida Gadea, 1973 \\ Family Diplopeltoididae Tchesunov, 1990 (monotypic)
}

Genus Diplopeltoides Gerlach, 1962

\section{Type species}

Diplopeltoides ornatus (Gerlach, 1950).

Diagnosis (emended after Holovachov 2014)

Cuticle annulated, annulation starts at level with the amphids; annules smooth or with fine longitudinal striation. Annules unequal in width; annule width increases gradually from first postcephalic annule to annule located somewhat posterior to the pharyngo- intestinal junction, which is followed by a much narrower one; annules increase in width posterior towards mid-body region. Posterior to two-thirds of body length, annule width gradually decreases again, with the most narrow annule located on tail; the most narrow caudal annule is followed posteriorly by one much wider annule and then by caudal annules, in which the width gradually decreases toward the tail terminus. Lateral alae absent. Body pores and epidermal glands absent. Somatic sensilla present. Labial region bluntly rounded; lip pairs fused into three small lobes. Inner labial sensilla invisible if present. Outer labial sensilla pore-like, located on the anterior surface of lips. Cephalic sensilla setiform or papilliform; their bases located at the base of the labial region, anterior to amphid. Subcephalic and cervical sensilla, deirid and ocelli absent. Amphids in some species lie on strongly cuticularised lateral subcuticular plates that are partly or completely connected together on the ventral and dorsal sides forming a "cephalic framework". Amphidial fovea loop-shaped (inverted U-shaped). Secretory-excretory system usually present; renette cell elongate, located opposite to the cardia and anterior part of intestine. Secretory-excretory ampulla present, located at the level of the posterior part of pharynx. Cuticularized secretory-excretory duct very short, opens to the exterior posterior to the nerve ring level. Buccal cavity small funnel-shaped: cheilostom can usually be seen as the cylindrical or funnel-shaped anterior-most part, not cuticularised; gymnostom short and not cuticularised; stegostom closed, linear, its slender lining continuous with that of the corpus. Pharyngeal tubes absent. Pharynx subdivided by breaks in muscular tissue into anterior corpus and posterior postcorpus; corpus cylindrical or fusiform, muscular, with evenly distributed myofilaments; postcorpus glandular, consisting of anterior narrower isthmus and basal swelling; dorsal sector of the basal bulb is often enlarged to accommodate dorsal pharyngeal gland; pharyngeal lumen uniform in thickness along the entire pharynx length; valves absent. Dorsal and two subventral gland orifices penetrate pharyngeal lumen at the base of stoma. Dorsal gland nucleus is visible in the basal swelling. Cardia conoid, glandular. Female reproductive system didelphic-amphidelphic with equally developed branches, ovaries reflexed antidromously. Spermatheca absent. Vulva equatorial, transverse 
or pore-like. Vagina straight; pars proximalis vaginae encircled by sphincter muscle; pars refringens vaginae and epiptygmata absent. Male reproductive system diorchic, testes outstretched or opposed in different species. Spicules symmetrical, arcuate; gubernaculum usually present. Supplements, precloacal and postcloacal sensilla absent. Setae in caudal region of males arranged in subventral and subdorsal pairs along the tail. Three caudal glands present, open via three separate openings, their nuclei are incaudal. Spinneret absent.

\section{Valid species}

Diplopeltoides anatolii (Voronov, 1982)

= Diplopeltula anatolii Voronov, 1982

Diplopeltoides asetosus (Juario, 1974) comb. nov.

= Diplopeltula asetosa Juario, 1974

Diplopeltoides axayacatli Holovachov, Tandingan De Ley, Mundo-Ocampo, Gingold \& De Ley, 2009

Diplopeltoides botulus (Wieser, 1959) comb. nov.

= Diplopeltula botula Wieser, 1959

Diplopeltoides bulbosus (Vitiello, 1972) comb. nov.

= Diplopeltula bulbosa Vitiello, 1972

Diplopeltoides grandis sp. nov.

Diplopeltoides linkei Jensen, 1991

Diplopeltoides longicaudatus sp. nov.

Diplopeltoides lucanicus (Boucher \& Helléouët, 1977) comb. nov.

= Diplopeltula lucanica Boucher \& Helléouët, 1977

Diplopeltoides mastigia Tchesunov, 1990

Diplopeltoides nudus (Gerlach, 1956)

= Diplopeltula nuda Gerlach, 1956

Diplopeltoides ornatus (Gerlach, 1950)

= Diplopeltis ornatus Gerlach, 1950

Diplopeltoides paramastigia Holovachov, Tandingan De Ley, Mundo-Ocampo, Gingold \& De Ley, 2009

Diplopeltoides pulcher (Vincx \& Gourbault, 1992)

= Diplopeltula pulchra Vincx \& Gourbault, 1992

Diplopeltoides pumilus (Vincx \& Gourbault, 1992) comb. nov.

= Diplopeltula pumila Vincx \& Gourbault, 1992

= Diplopeltoides holovachovi Fadeeva \& Mordukhovich, 2013 syn. nov.

Diplopeltoides santaclarae Holovachov, Tandingan De Ley, Mundo-Ocampo, Gingold \& De Ley, 2009

Diplopeltoides striatus (Gerlach, 1956) comb. nov.

= Diplopeltula striata Gerlach, 1956

Diplopeltoides suecicus sp. nov.

Diplopeltoides sundensis (Jensen, 1978)

= Diplopeltula sundensis Jensen, 1978

\section{Nomenclatorial changes}

1) Diplopeltula asetosa Juario, 1974 is here transferred to the genus Diplopeltoides based on the morphology of the female reproductive system with reflexed ovaries in this species vs outstretched ovaries as defined for the genus Diplopeltula by Fonseca \& Bezerra (2014) and Leduc (2017).

2) Diplopeltula botula Wieser, 1959 is here transferred to the genus Diplopeltoides based on the fact that it shows no qualitative differences from several species currently assigned to the genus Diplopeltoides. 
3) Diplopeltula bulbosa Vitiello, 1972 is here transferred to the genus Diplopeltoides based on the morphology of the female reproductive system with reflexed ovaries in this species vs outstretched ovaries as defined for the genus Diplopeltula by Fonseca \& Bezerra (2014) and Leduc (2017).

4) Diplopeltula lucanica Boucher \& Helléouët, 1977 is here transferred to the genus Diplopeltoides based on the characteristic morphology of the amphid (with a crenate interamphideal shield - a feature common to other species of Diplopeltoides, but not in Diplopeltula and its type species Diplopeltula breviceps Gerlach, 1950).

5) Diplopeltula pumila Vincx \& Gourbault, 1992 is here transferred to the genus Diplopeltoides based on its close morphological affinities to Diplopeltoides holovachovi Fadeeva \& Mordukhovich, 2013 in general morphology, structure of cuticle, anterior end and spicules. Since the only known difference between the two species is in the length of the spicules, Diplopeltoides holovachovi is here considered a junior synonym of Diplopeltoides pumilus.

6) Diplopeltula striata Gerlach, 1956 is here transferred to the genus Diplopeltoides based on unpublished observations on the morphology of the female reproductive system (reflexed ovaries) in this species.

Diplopeltoides suecicus sp. nov. urn:lsid:zoobank.org:act:BD6CBB55-4DF6-4E17-802B-093C3DE95BD5

Figs 1-3; Table 1

\section{Diagnosis}

Diplopeltoides suecicus sp. nov. is characterised by a body of $0.82-1.02 \mathrm{~mm}$ long; cuticle with longitudinal striation visible only under SEM; cuticularised plate underlying cephalic cuticle around amphid present; cephalic sensilla setiform, 4-6 $\mu \mathrm{m}$ long; amphidial fovea an inverted U-shape, 14$21 \mu \mathrm{m}$ long and 6-9 $\mu \mathrm{m}$ wide; wide space between amphidial branches areolated; secretory-excretory pore located opposite to basal pharyngeal swelling; tail subcylindrical with bluntly rounded terminus; testes outstretched; spicules 27-31 $\mu \mathrm{m}$ long, strongly curved, with weakly defined manubrium and subcylindrical shaft; gubernaculum plate-like, with caudal apophyses.

\section{Etymology}

The specific epithet "suecicus" (masculine) - Swedish, refers to the country where the new species was first discovered.

\section{Type material}

\section{Holotype}

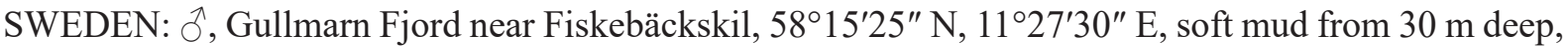
11 Aug. 2011, O. Holovachov leg. (SMNH Type-8840).

\section{Paratypes}

SWEDEN: 4 우, $1 \bigcirc^{\lambda}$, Gullmarn Fjord near Fiskebäckskil, 58 $15^{\prime} 25^{\prime \prime} \mathrm{N}, 1^{\circ} 27^{\prime} 30^{\prime \prime}$ E, soft mud from $30 \mathrm{~m}$ deep, 11 Aug. 2011, O. Holovachov leg. (SMNH Type-8841); 1 ㅇ, 2 $\hat{\jmath}$, Gullmarn Fjord near

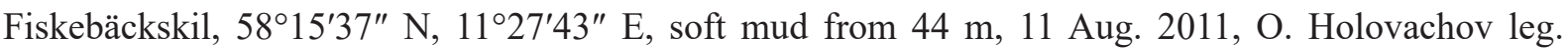
(SMNH Type-8842). 


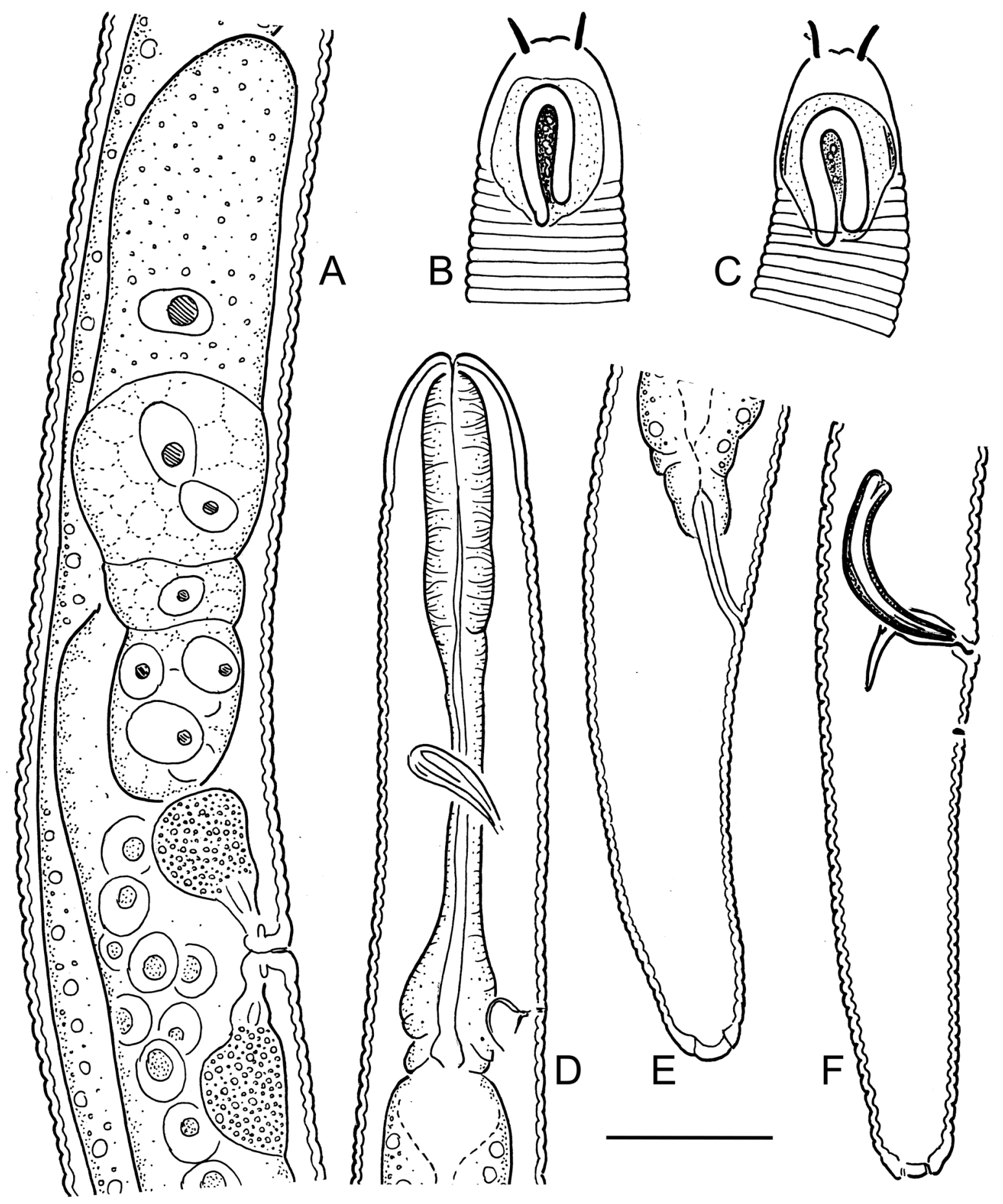

Fig. 1. Diplopeltoides suecicus sp. nov. A. Anterior part of the female reproductive system. B. Female anterior end, surface view. C. Male anterior end, surface view. D. Female pharyngeal region, optical median section. E. Female tail. F. Male tail. Scale bar $=20 \mu \mathrm{m}$. 


\section{Description}

\section{Adult}

Body cylindrical, posteriorly tapering in the tail region, straight or weakly ventrally curved upon fixation. Cuticle coarsely annulated along entire body, except for visually smooth anterior end (faint annulation is visible under the scanning electron microscope) and terminal part of the tail; annules 1.5-2.5 $\mu \mathrm{m}$ wide at mid-body region; longitudinal striation not observed under the light microscope but distinct under the scanning electron microscope, covers annules over entire body length. Somatic setae visible on tail. Labial region bluntly rounded, lips fused. Cuticularised plate underlying cephalic cuticle around amphid, extending from the level of the anteriormost edge of amphid to the posteriormost edge of amphid, 17$21.5 \mu \mathrm{m}$ long and $12-14.5 \mu \mathrm{m}$ wide at its base; cuticular plates are connected with each other on ventral and on dorsal sides. Inner labial sensilla not seen; outer labial sensilla small papilliform, located on the anterior surface of lips. Cephalic sensilla setiform, equal to 0.5-0.8 labial region diameters in length, their bases are located 1.5-2 $\mu \mathrm{m}$ from anterior end. Amphids similar in shape and size between sexes: amphidial fovea an inverted U-shape with its dorsal branch longer than ventral branch. Wide space
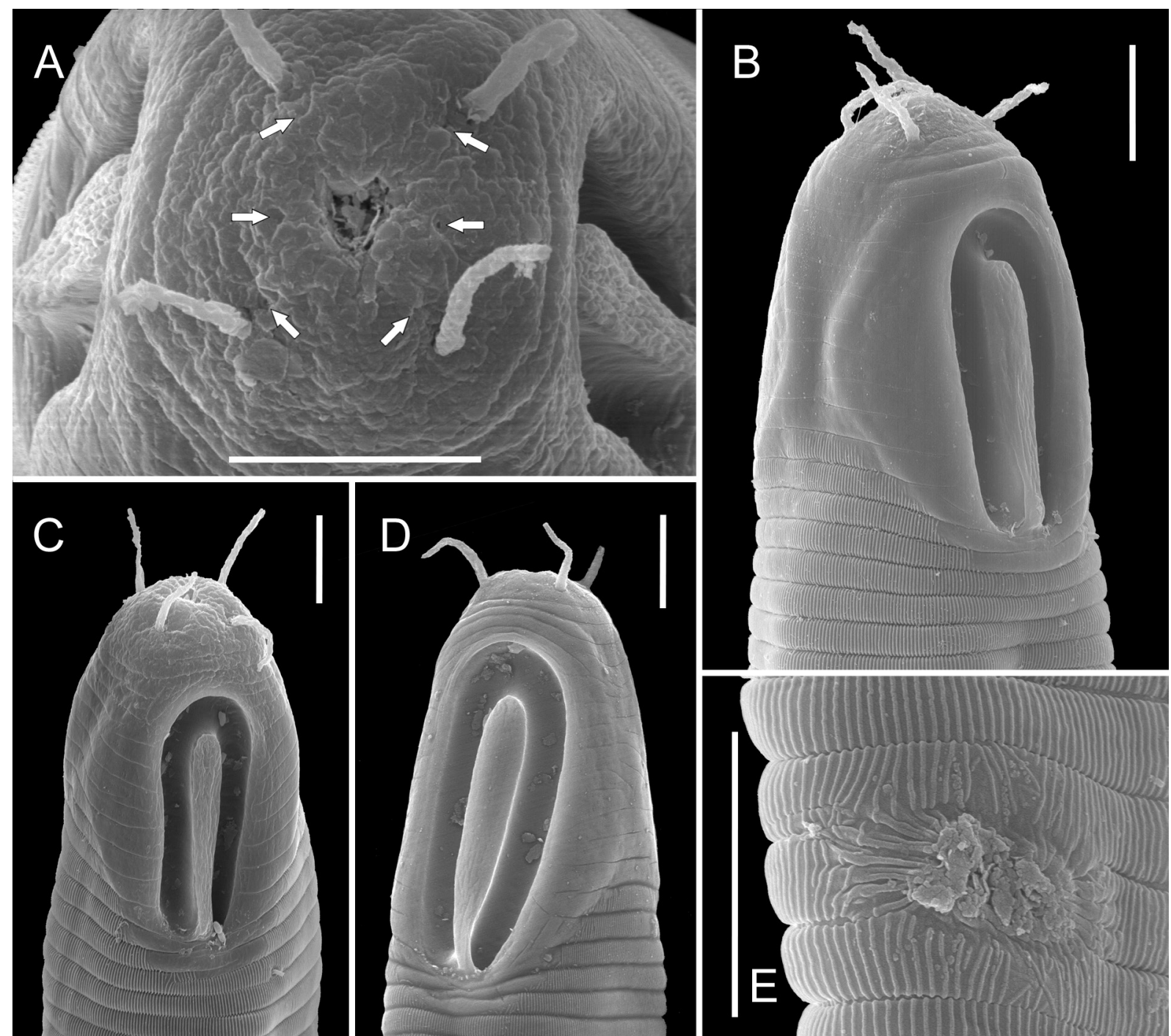

Fig. 2. Diplopeltoides suecicus sp. nov. SEM micrographs. A, C-D. Male. B, E. Female. A. Anterior end, apical view (arrows point at outer labial sensilla). B-D. Anterior end, left sublateral view. E. Vulval region. Scale bars: $\mathrm{A}-\mathrm{E}=5 \mu \mathrm{m}$. 


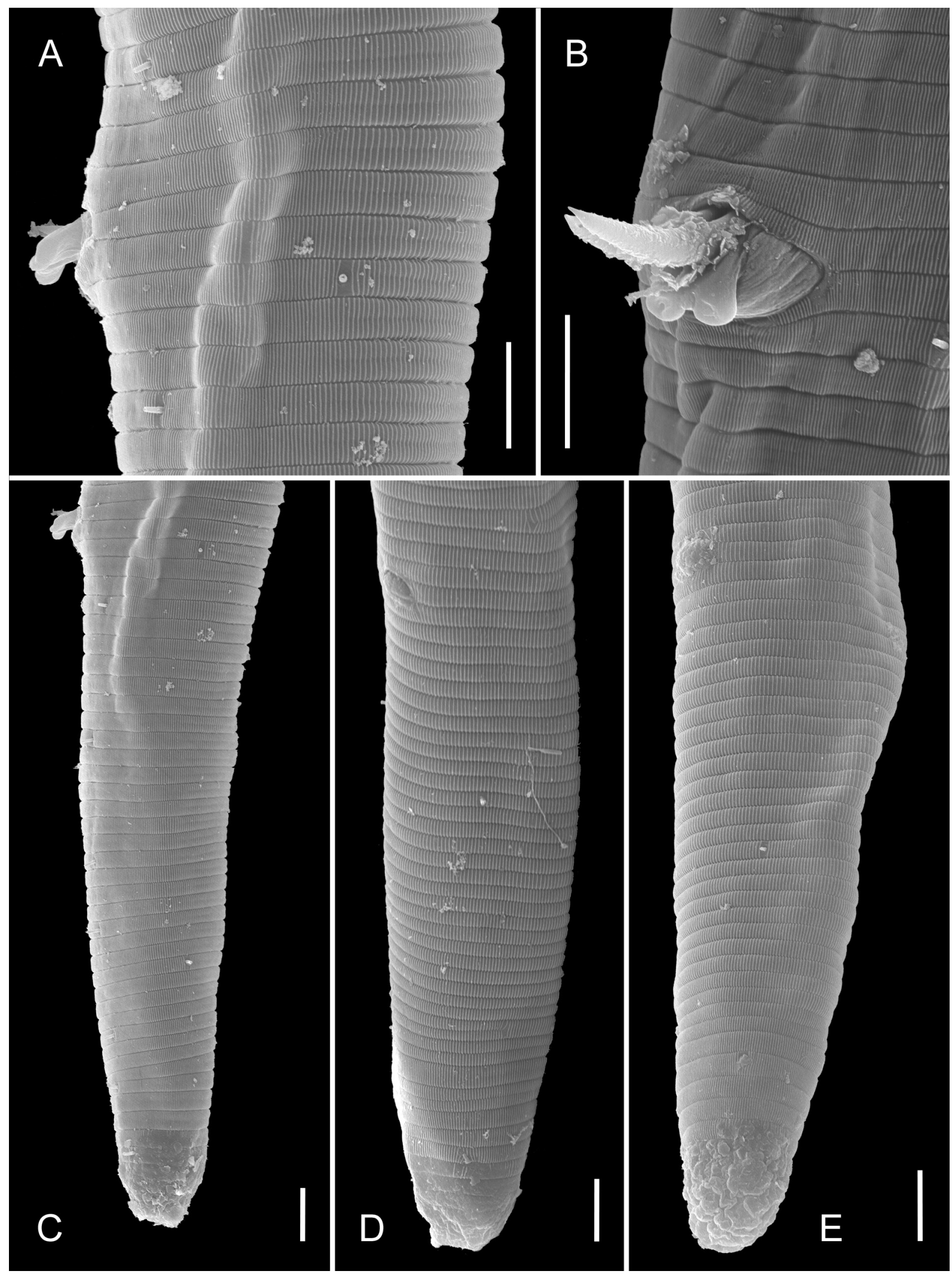

Fig. 3. Diplopeltoides suecicus sp. nov. SEM micrographs. A. Male cloacal region, lateral view. B. Male cloacal region, ventrosubventral view. C. Male tail, lateral view. D-E. Female tail, ventrosublateral view. Scale bars: $\mathrm{A}-\mathrm{E}=5 \mu \mathrm{m}$. 
Table 1. Measurements (in $\mu \mathrm{m}$ ) of Diplopeltoides suecicus sp. nov., presented as mean and (range).

\begin{tabular}{|c|c|c|c|}
\hline Sex & Holotype male & Female & Male \\
\hline Number of specimens & 1 & 5 & 4 \\
\hline Body length & 932 & $896(821-980)$ & $963(932-1018)$ \\
\hline Body diameter (BD) & 23 & $32(30-33)$ & $22(19-24)$ \\
\hline Pharynx length & 87 & $87(81-92)$ & $88(87-90)$ \\
\hline Tail length & 67 & $60(57-67)$ & $73(67-83)$ \\
\hline Anal body diameter (ABD) & 19 & $20(18-21)$ & $21(19-23)$ \\
\hline $\mathrm{a}$ & 40.9 & $28.1(24.8-33.1)$ & $44.8(39.1-49.8)$ \\
\hline $\mathrm{b}$ & 10.8 & $10.3(9.6-10.9)$ & $10.9(10.4-11.3)$ \\
\hline $\mathrm{c}$ & 13.8 & $14.9(14.2-15.9)$ & $13.2(12.2-13.9)$ \\
\hline$c^{\prime}$ & 3.5 & $3.1(2.8-3.4)$ & $3.6(3.5-3.7)$ \\
\hline $\mathrm{V}$ or $\mathrm{T}(\%)$ & 52.0 & $52.9(50.0-55.3)$ & $73.0(52.0-92.8)$ \\
\hline Labial region diameter & 8.0 & $8.6(8.0-9.0)$ & $8.1(7.5-8.0)$ \\
\hline Cephalic setae length & 6.0 & $5.0(4.0-6.0)$ & $5.7(5.5-6.0)$ \\
\hline Amphid from anterior end & 7.5 & $5.8(5.5-6.0)$ & $6.7(5.5-7.5)$ \\
\hline Dorsal amphid branch length & 17.0 & $15.5(14.0-16.5)$ & $17.9(15.0-21.0)$ \\
\hline Ventral amphid branch length & 15.0 & $14.5(13.0-17.0)$ & $17.1(15.0-19.0)$ \\
\hline Amphid width & 8.0 & $6.6(6.0-7.0)$ & $7.8(6.0-9.0)$ \\
\hline Nerve ring from anterior end & 56 & $55(51-63)$ & 56 \\
\hline $\begin{array}{l}\text { Nerve ring from anterior end as } \% \text { of } \\
\text { pharynx length }\end{array}$ & 65 & $64(56-73)$ & 65 \\
\hline Secretory-excretory pore from ant. end & 74 & $75(63-82)$ & $80(74-84)$ \\
\hline $\begin{array}{l}\text { Secretory-excretory pore from ant. end } \\
\text { as } \% \text { of pharynx length }\end{array}$ & 86 & $86(78-92)$ & $90(86-94)$ \\
\hline Anterior gonad length (to flexure) & - & $104(83-114)$ & - \\
\hline Posterior gonad length (to flexure) & - & $113(93-124)$ & - \\
\hline Vagina or spicules length & 27 & $8(6-10)$ & $29(27-31)$ \\
\hline Rectum or gubernaculum length & 9 & $16(14-18)$ & $8(6-9)$ \\
\hline Vagina length / BD & - & $0.2(0.2-0.3)$ & - \\
\hline Rectum or spicules / ABD & 1.4 & $0.8(0.7-0.9)$ & $1.4(1.3-1.5)$ \\
\hline
\end{tabular}

between amphidial branches (amphidial shield) strongly cuticularised and areolated. Stoma very small, its cuticularised lining is uniform with the lining of the pharynx. Pharynx distinctly subdivided into anterior corpus and posterior postcorpus; corpus cylindrical or slightly fusiform, muscular; postcorpus consists of anterior narrow non-muscular isthmus and pear-shaped glandular basal swelling. Pharyngeal gland nuclei and orifices indistinct. Nerve ring surrounding isthmus. Secretory-excretory system present; secretory-excretory pore located along the ventral body line opposite to basal pharyngeal swelling; secretory-excretory duct very short, leading from pore to ampulla; renette cell small, its body adjacent and ventral to anterior part of intestine. Tail subcylindrical with bluntly rounded terminus. Caudal glands opening via three separate openings, spinneret absent. 


\section{Female}

Reproductive system didelphic, amphidelphic, reflexed; ovary branches symmetrical. Anterior ovary situated to either right or left of intestine; posterior ovary situated to either right or left of intestine. Vulva pore-like, located at or immediately posterior to mid-body. Vagina straight, $0.2-0.3$ of the vulval body diameter, with developed sphincter muscle at its proximal part; pars refringens vaginae absent. Intrauterine egg not seen; sperm is often present in the uterus. Rectum short, $0.7-0.9$ of the corresponding body diameter long.

\section{Male}

Reproductive system diorchic, both testes outstretched. Spicules paired and symmetrical, strongly curved, with weakly defined manubrium and subcylindrical shaft. Gubernaculum plate-like, with a pair of strong closely set caudal apophyses. Caudal setae present, arranged in subventral and subdorsal rows, but difficult to observe and count.

\section{Remarks}

Diplopeltoides suecicus sp. nov. is most similar to D. axayacatli and D. grandis sp. nov. in having strongly developed cuticularised plate and amphid with wide and ornamented interamphideal shield. The new species differs from D. axayacatli in the shape of the amphid (loop-shaped vs hook-shaped in $D$. axayacatli), shorter cephalic setae (4-6 $\mu \mathrm{m}$ vs $15-20 \mu \mathrm{m}$ in $D$. axayacatli), gubernaculum with strong apophyses (vs without apophyses in $D$. axayacatli) and shorter tail (c' $=2.8-3.7$ vs $5.0-6.0$ in $D$. axayacatli); it differs from $D$. grandis sp. nov. in shorter body $(0.82-1.02 \mathrm{~mm}$ vs $2.06 \mathrm{~mm}$ in $D$. grandis sp. nov.) and shorter cephalic setae (4-6 $\mu \mathrm{m}$ vs $18.5 \mu \mathrm{m}$ in $D$. grandis sp. nov.).

Diplopeltoides asetosus (Juario, 1974) comb. nov.

Fig. 4; Table 2

\section{Diagnosis}

Diplopeltoides asetosus is characterised by a body of 0.76-1.19 mm long; cuticle without longitudinal striation; cuticularised plate absent; cephalic sensilla setiform, 3.5-7.0 $\mu \mathrm{m}$ long; amphidial fovea an inverted U-shape, 14-19 $\mu \mathrm{m}$ long and 6-9 $\mu \mathrm{m}$ wide; wide space between amphidial branches punctuated or crenate; secretory-excretory pore located opposite to basal pharyngeal swelling; tail subcylindrical with rounded terminus; testes outstretched; spicules $17-31 \mu \mathrm{m}$ long, strongly curved, with dorsally bent manubrium and subcylindrical shaft; gubernaculum plate-like, with caudal apophyses.

\section{Material examined}

SWEDEN: 1 क, Skagerrak, 58 $20^{\prime} 06^{\prime \prime} \mathrm{N}, 11^{\circ} 09^{\prime} 24^{\prime \prime} \mathrm{E}$, muddy sediment from $53 \mathrm{~m}$ deep, 9 Aug. 2011,

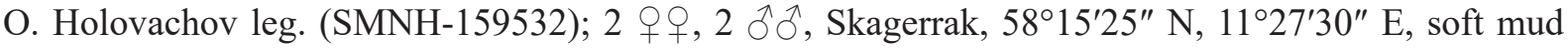
from $30 \mathrm{~m}$ deep, 11 Aug. 2011, O. Holovachov leg. (SMNH-159533-534); 1 q, Skagerrak, 58 15'37" N,

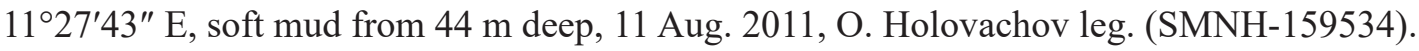

\section{Description}

Adult

Body cylindrical, posteriorly tapering in tail region, straight or ventrally curved upon fixation, more so in the posterior part of males. Cuticle coarsely annulated along entire body, except for smooth anterior end and terminal part of the tail; annules 1.5-2.5 $\mu \mathrm{m}$ wide at mid-body region; longitudinal striation not observed under the light microscope. Somatic setae visible on tail. Labial region bluntly rounded, lips fused. Cuticularised plate underlying cephalic cuticle around amphid absent. Inner and outer labial sensilla not seen. Cephalic sensilla setiform, equal to 0.3-0.6 labial region diameters in length, their bases are located 3-3.5 $\mu \mathrm{m}$ from anterior end. Amphids similar in shape and size between 
sexes: amphidial fovea an inverted U-shape with dorsal branch longer than ventral branch. Wide space between amphidial branches (amphidial shield) strongly cuticularised, punctuated or crenate. Stoma very small, its cuticularised lining is uniform with lining of pharynx. Pharynx distinctly subdivided into anterior corpus and posterior postcorpus; corpus cylindrical or slightly fusiform, muscular; postcorpus consists of anterior narrow non-muscular isthmus and pear-shaped glandular basal swelling. Pharyngeal gland nuclei and orifices indistinct. Nerve ring surrounding isthmus. Secretory-excretory system present; secretory-excretory pore located along ventral body line opposite to basal pharyngeal swelling; secretory-excretory duct very short, leading from pore to ampulla; renette cell ovoid, its body adjacent and ventrosublateral to anterior part of intestine. Tail subcylindrical with rounded terminus. Caudal glands opening via three separate openings, spinneret absent.

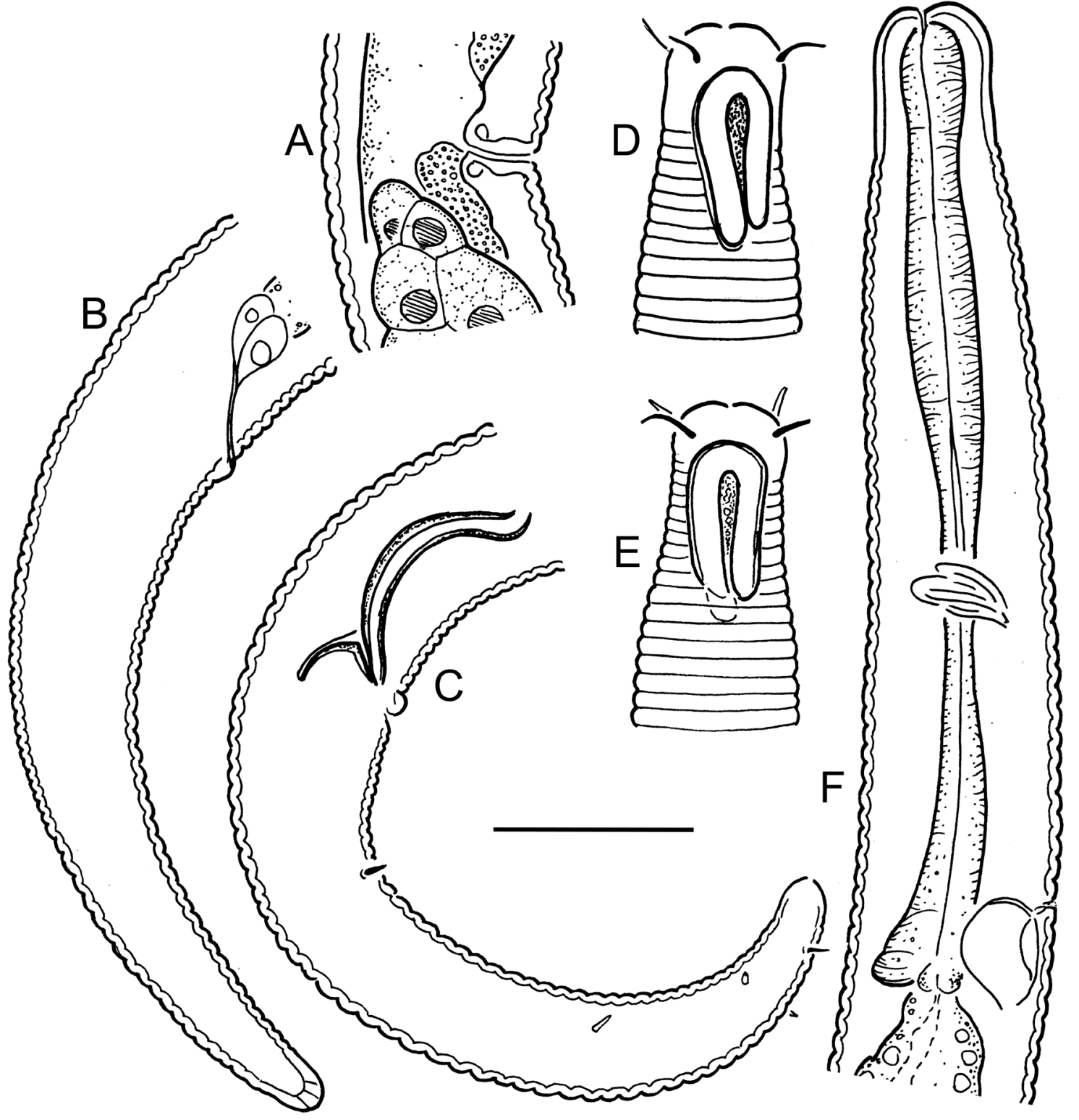

Fig. 4. Diplopeltoides asetosus (Juario, 1974) comb. nov. A. Vulval region. B. Female tail. C. Male tail. D. Female anterior end, surface view. E. Male anterior end, surface view. F. Female pharyngeal region, optical median section. Scale bar $=20 \mu \mathrm{m}$. 
Table 2. Measurements (in $\mu \mathrm{m}$ ) of Diplopeltoides asetosus (Juario, 1974) comb. nov., presented as mean and (range) for females and each male individual measurement separated with a semicolon; "?" indicates that the character can not be observed or measured.

\begin{tabular}{lcc}
\hline Sex & Female & Male \\
\hline Number of specimens & 4 & 2 \\
Body length & $993(866-1190)$ & $1050 ; 1064$ \\
Body diameter (BD) & $24(21-28)$ & $21 ; 21$ \\
Pharynx length & $103(100-107)$ & $104 ; 100$ \\
Tail length & $84(71-96)$ & $83 ; 89$ \\
Anal body diameter (ABD) & $16(15-17)$ & $16 ; 18$ \\
a & $42.0(31.7-52.2)$ & $51.2 ; 51.9$ \\
b & $9.6(8.6-11.1)$ & $10.1 ; 10.6$ \\
c & $11.9(10.6-12.4)$ & $12.6 ; 12.0$ \\
c' & $5.1(4.1-5.7)$ & $5.2 ; 4.9$ \\
V or T (\%) & $52.8(50.9-54.5)$ & $? ; 51.5$ \\
Labial region diameter & $10.7(10.0-12.0)$ & $11.0 ; 10.5$ \\
Cephalic setae length & $4.8(3.5-5.5)$ & $6.0 ; 5.0$ \\
Amphid from anterior end & $4.8(4.0-6.0)$ & $3.5 ; 5.5$ \\
Dorsal amphid branch length & $16.6(14.0-18.5)$ & $18.0 ; 16.5$ \\
Ventral amphid branch length & $14.5(12.0-16.5)$ & $16.0 ; 14.5$ \\
Amphid width & $7.4(6.0-8.0)$ & $7.5 ; 7.5$ \\
Nerve ring from anterior end & $61(58-64)$ & $? ; 55$ \\
Nerve ring from anterior end as \% of & $60(58-62)$ & $? ; 55$ \\
pharynx length & $90(87-94)$ & $96 ; 86$ \\
Secretory-excretory pore from ant. end & $87(85-91)$ & $92 ; 85$ \\
Secretory-excretory pore from ant. end & $112(46-154)$ & - \\
as \% of pharynx length & $121(60-159)$ & - \\
Anterior gonad length (to flexure) & $7(7-8)$ & $1.9 ; 1.4$ \\
Posterior gonad length (to flexure) & $14(12-17)$ & \\
Vagina or spicules length & 0.3 & - \\
Rectum or gubernaculum length & $0.8(0.7-1.0)$ & \\
Vagina length / BD & & \\
Rectum or spicules length / ABD & & \\
\hline
\end{tabular}

\section{Female}

Reproductive system didelphic, amphidelphic, reflexed; ovary branches symmetrical. Anterior ovary situated to right of intestine; posterior ovary situated to left of intestine. Vulva at or immediately posterior to mid-body. Vagina straight, 0.3 of the vulval body diameter, with developed sphincter muscle at its proximal part; pars refringens vaginae absent. Intrauterine egg not seen; sperm is visible in the uterus. Rectum short, $0.7-1$ of the corresponding body diameter long. 


\section{Male}

Reproductive system diorchic, both testes outstretched. Spicules paired and symmetrical, strongly curved, with dorsally bent manubrium and subcylindrical shaft. Gubernaculum plate-like, with a pair of strong closely set caudal apophyses. Caudal setae present, arranged in subventral and subdorsal rows but difficult to observe and count.

\section{Remarks}

The recently collected population of $D$. asetosus is similar to the type specimens in general morphology and measurements, except for the relatively broader amphid and longer spicules $(26-31 \mu \mathrm{m}$ vs $17 \mu \mathrm{m}$ (along chord) in the text of the original description or $21 \mu \mathrm{m}$ as re-measured along curved median line using the original drawing).

Diplopeltoides bulbosus (Vitiello, 1972) comb. nov. Figs 5-6, 11A; Table 3

\section{Diagnosis}

Diplopeltoides bulbosus is characterised by by a body of $1.12-1.58 \mathrm{~mm}$ long; cuticle with longitudinal striation visible only under SEM; cuticularised plate absent; cephalic sensilla papilliform, $1-2 \mu \mathrm{m}$ long; amphidial fovea an inverted U-shape, 21-28 $\mu \mathrm{m}$ long and 7-11 $\mu \mathrm{m}$ wide, with fine striation; narrow space between amphidial branches not cuticularised; secretory-excretory pore located opposite to basal pharyngeal swelling; tail cylindrical or clavate with bluntly rounded terminus; testes outstretched; spicules 34-50 $\mu \mathrm{m}$ long, strongly curved, with dorsally bent manubrium and subcylindrical, gradually narrowing shaft; gubernaculum plate-like, with or without caudal apophysis.

\section{Material examined}

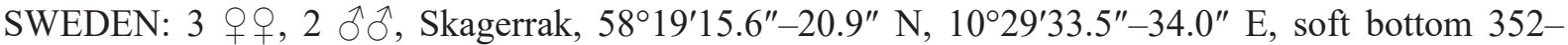
$374 \mathrm{~m}$ deep, 10 Oct. 2012, "Inventering Bratten" leg. (SMNH-159537); 1 ô, soft bottom 232-240 m

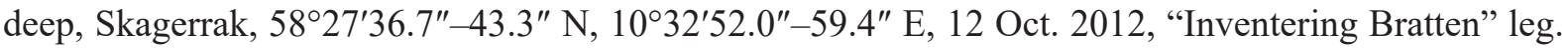

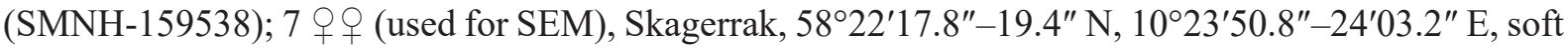
bottom 351-387 m deep, 10 Oct. 2012, "Inventering Bratten" leg.

\section{Description}

Adult

Body cylindrical, posteriorly tapering in the tail region, straight or variously curved upon fixation. Cuticle coarsely annulated along entire body, except for smooth anterior end and terminal part of tail; annules $2.5-3 \mu \mathrm{m}$ wide at mid-body region; longitudinal striation not observed under light microscope, but distinct under scanning electron microscope, covers annules over most of body length, except for anteriormost and posteriormost parts. Somatic setae present along pharyngeal region and on tail. Labial region bluntly rounded. Cuticularised plate underlying cephalic cuticle around amphid absent. Inner and outer labial sensilla not seen. Cephalic sensilla papilliform, equal to 0.1 labial region diameter in length, their bases are located 3.5-6 $\mu \mathrm{m}$ from anterior end. Amphids similar in shape and size between sexes: amphidial fovea an inverted U-shape with ventral branch longer than dorsal branch; tip of ventral branch bent to dorsal side. Interior of amphideal fovea with fine striation visible under light and scanning electron microscopes. Narrow space between amphidial branches (amphidial shield) not cuticularised. Stoma very small, its cuticularised lining uniform with lining of pharynx. Pharynx distinctly subdivided into anterior corpus and posterior postcorpus; corpus cylindrical or slightly fusiform, muscular; postcorpus consists of anterior narrow non-muscular isthmus and pear-shaped glandular basal swelling. Pharyngeal gland nuclei and orifices indistinct. Nerve ring surrounding isthmus. Secretory-excretory system present; secretory-excretory pore located along ventral body line opposite to basal pharyngeal 




A
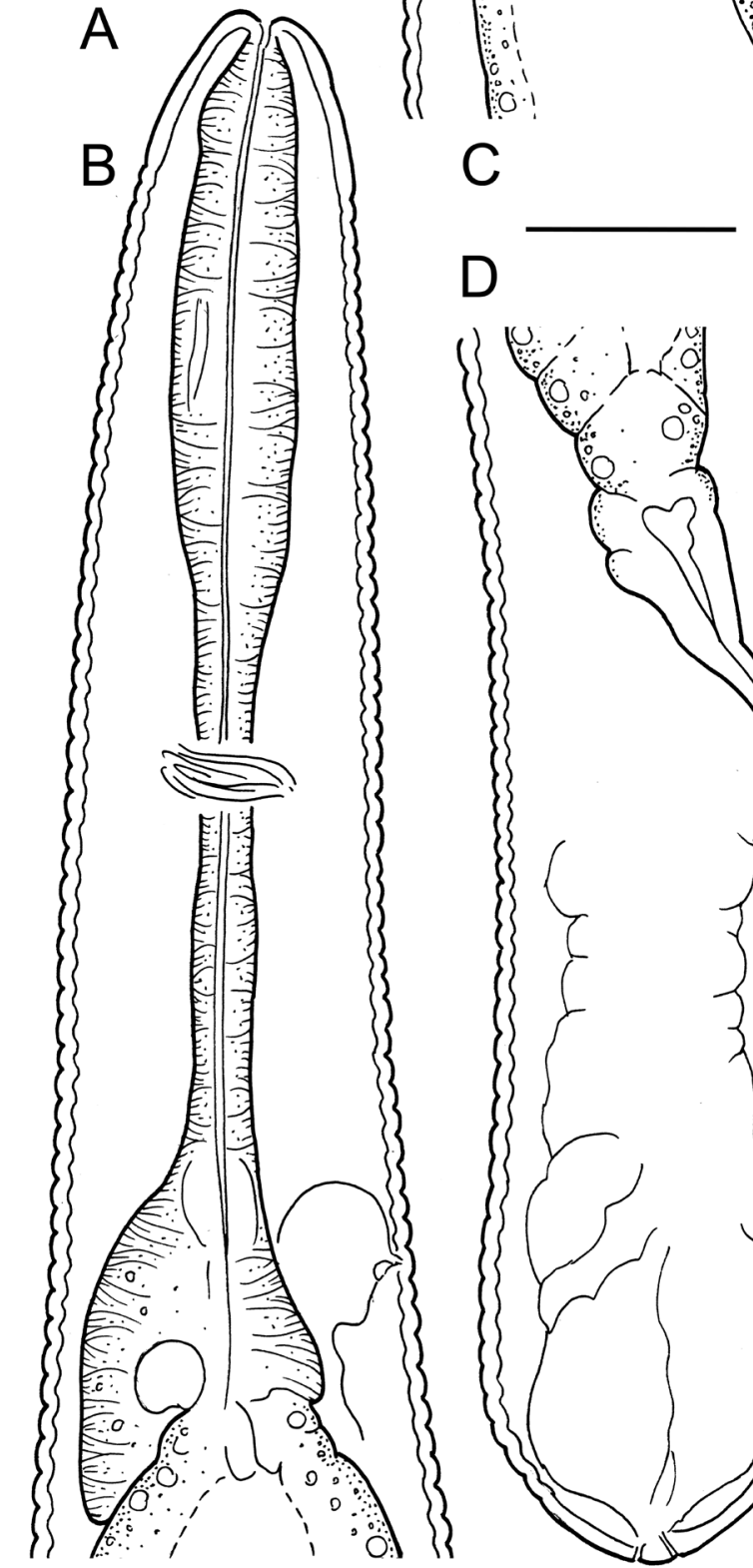
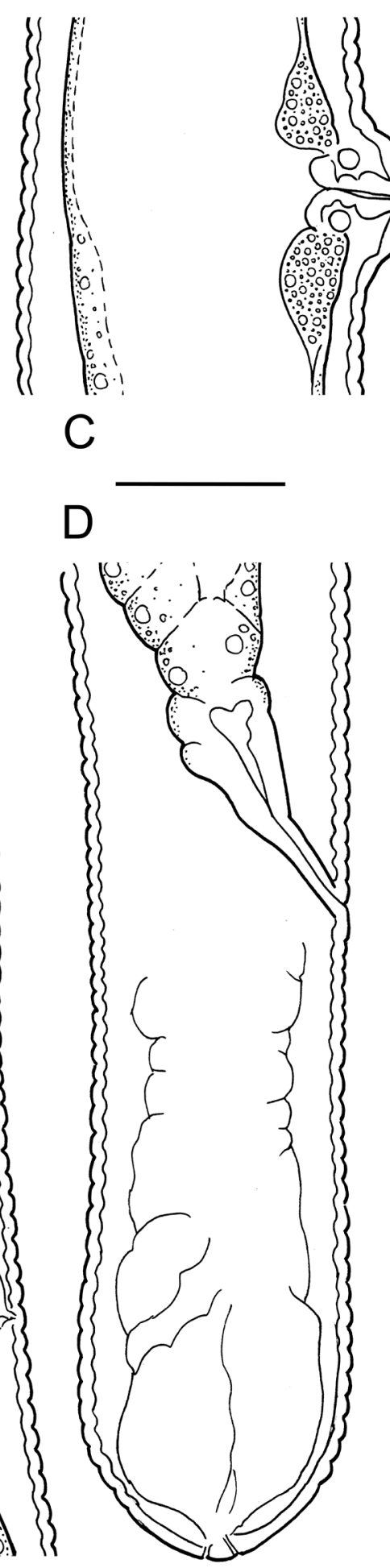
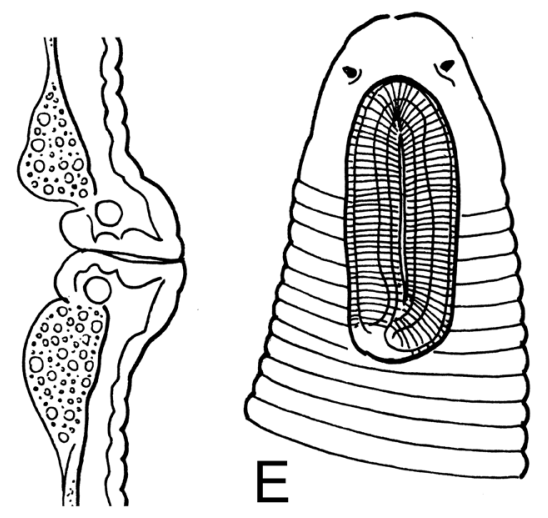

\}) $F$

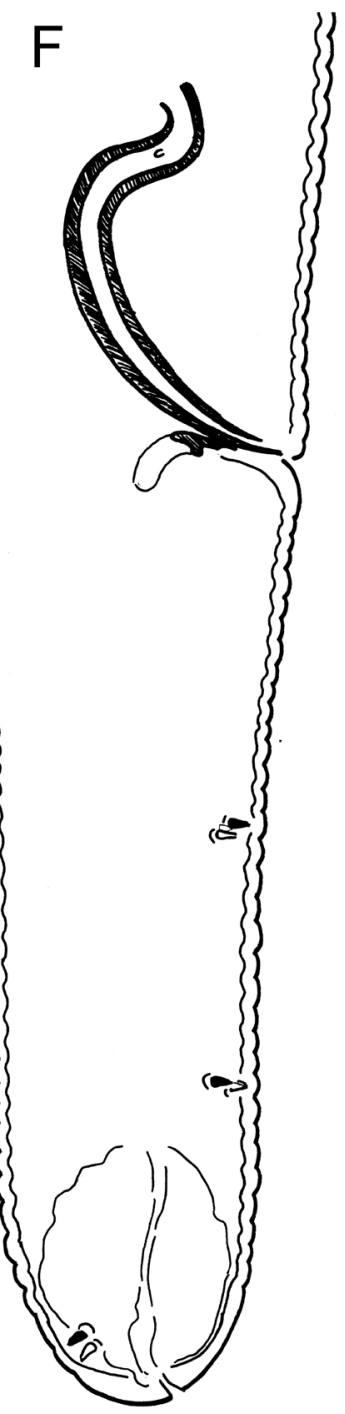

Fig. 5. Diplopeltoides bulbosus (Vitiello, 1972) comb. nov. A. Female anterior end, surface view. B. Female pharyngeal region, optical median section. C. Vulval region. D. Female tail. E. Male anterior end, surface view. F. Male tail. Scale bar $=20 \mu \mathrm{m}$. 
swelling; secretory-excretory duct very short, leading from pore to ampulla; renette cell obscure. Tail cylindrical or clavate, with bluntly rounded terminus. Caudal glands opening via three separate openings, spinneret absent.

\section{Female}

Reproductive system didelphic, amphidelphic, reflexed; ovary branches symmetrical. Anterior ovary situated to either right (usually) or left (rarely) of intestine; posterior ovary situated to either left (usually) or right (rarely) of intestine. Vulva pore-like, located posterior to mid-body. Vagina straight, $0.3-0.4$ of vulval body diameter, with thick walls and developed sphincter muscle at proximal part; pars
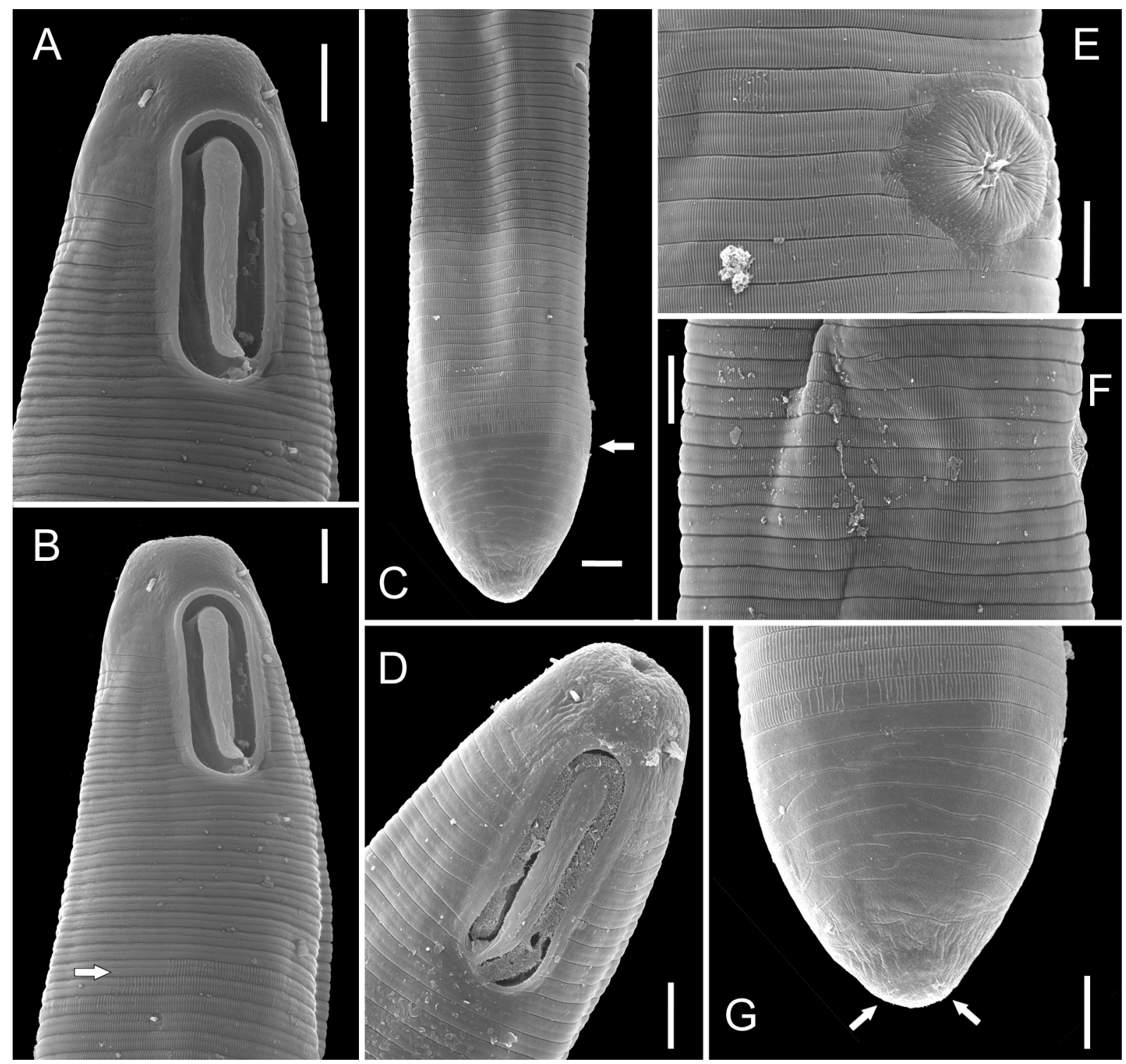

Fig. 6. Diplopeltoides bulbosus (Vitiello, 1972) comb. nov. SEM micrographs of females. A-B. Anterior end, right sublateral view (arrow points at the anterior edge of longitudinal striation of cuticle). C. Female tail (arrow points at the posterior edge of the longitudinal striation of the cuticle). D. Anterior end, left sublateral view. E. Vulval region, ventrosublateral view. F. Vulval region, lateral view. G. Tail terminus (arrows point at openings of caudal glands. Scale bars: $A-G=5 \mu \mathrm{m}$. 
Table 3. Measurements (in $\mu \mathrm{m}$ ) of Diplopeltoides bulbosus (Vitiello, 1972) comb. nov., presented as mean \pm s.d. (standard deviation) and (range) or mean and (range).

\begin{tabular}{lcc}
\hline Sex & Female & Male \\
\hline Number of specimens & 10 & 3 \\
Body length & $1411 \pm 82(1277-1573)$ & $1363(1159-1501)$ \\
Body diameter (BD) & $41 \pm 3(38-45)$ & $33(29-38)$ \\
Pharynx length & $131 \pm 6(122-140)$ & $133(124-140)$ \\
Tail length & $79 \pm 5(72-86)$ & $86(75-94)$ \\
Anal body diameter (ABD) & $30 \pm 2(26-34)$ & $29(26-32)$ \\
a & $34.8 \pm 2.4(31.6-38.6)$ & $40.8(39.9-41.8)$ \\
b & $10.8 \pm 0.8(9.1-11.8)$ & $10.3(9.3-11.3)$ \\
c & $18.0 \pm 1.4(16.1-20.3)$ & $15.9(15.3-16.9)$ \\
c' & $2.6 \pm 0.3(2.3-3.0)$ & $3.0(2.8-3.3)$ \\
V or T (\%) & $60.2 \pm 2.5(56.2-64.3)$ & $44.7(43.2-45.9)$ \\
Labial region diameter & $13.4 \pm 0.9(12.5-14.5)$ & $13.6(13.0-14.0)$ \\
Cephalic setae length & $1.4 \pm 0.3(1.0-2.0)$ & 1.5 \\
Amphid from anterior end & $6.7 \pm 1.1(5.0-8.0)$ & $5.5(5.0-6.0)$ \\
Dorsal amphid branch length & $22.3 \pm 0.9(21.5-24.0)$ & $26.7(25.5-27.5)$ \\
Ventral amphid branch length & $22.1 \pm 1.3(21.0-25.0)$ & $26.2(25.5-27.0)$ \\
Amphid width & $9.3 \pm 0.8(8.0-10.5)$ & $10.7(10.5-11.0)$ \\
Nerve ring from anterior end & $74 \pm 3(68-79)$ & $79(78-81)$ \\
Nerve ring from anterior end as \% of & $56 \pm 2(54-60)$ & 58 \\
pharynx length & $115 \pm 5(106-120)$ & $119(107-128)$ \\
Secretory-excretory pore from ant. end & $88 \pm 2(84-91)$ & $90(86-92)$ \\
Secretory-excretory pore from ant. end & $122 \pm 24(86-159)$ & - \\
as \% of pharynx length & $127 \pm 26(93-155)$ & - \\
Anterior gonad length (to flexure) & $13 \pm 2(10-15)$ & $1.6(1.5-1.9)$ \\
Posterior gonad length (to flexure) & $26 \pm 3(21-30)$ & \\
Vagina or spicules length & $0.3(0.3-0.4)$ & - \\
Rectum or gubernaculum length & $0.8 \pm 0.1(0.7-0.9)$ & \\
Vagina length / BD & & \\
Rectum or spicules length / ABD & & \\
\hline
\end{tabular}

refringens vaginae absent. Intrauterine egg not seen; sperm is visible in uterus. Rectum short, $0.7-0.9$ of corresponding body diameter long.

\section{Male}

Reproductive system diorchic, both testes outstretched. Spicules paired and symmetrical, strongly curved, with dorsally bent manubrium and subcylindrical, gradually narrowing shaft. Gubernaculum plate-like, with caudal apophysis that is variable in size and can be indistinct in some specimens. Caudal setae present, arranged in subventral and subdorsal rows, but difficult to observe. 


\section{Remarks}

The recently collected population of D. bulbosus is similar to type specimens in general morphology, measurements and shape of amphids, except for the spicule length. Vitiello (1972) stated in the original description that the spicules are $25 \mu \mathrm{m}$ long, compared to $45-50 \mu \mathrm{m}$ in our specimens. Measured from the drawings in the original description, the spicule length of the type specimen appears to be closer to $34 \mu \mathrm{m}$.

Diplopeltoides nudus (Gerlach, 1956)

Fig. 7; Table 4

\section{Diagnosis}

Diplopeltoides nudus is characterised by by a body of $0.94-1.35 \mathrm{~mm}$ long; cuticle without longitudinal striation; cuticularised plate absent; cephalic sensilla papilliform, 1-1.5 $\mu \mathrm{m}$ long; amphidial fovea an inverted U-shape, 17-28 $\mu \mathrm{m}$ long and 6-8 $\mu \mathrm{m}$ wide; narrow space between amphidial branches with crenated edge; secretory-excretory pore located opposite to basal pharyngeal swelling; tail subcylindrical with bluntly rounded terminus; testes outstretched; spicules 29-38 $\mu \mathrm{m}$ long, strongly curved, with dorsally bent manubrium and subcylindrical, gradually narrowing shaft; gubernaculum plate-like, with or without caudal apophyses.

\section{Material examined}

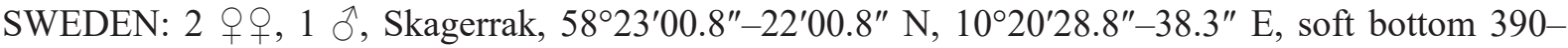

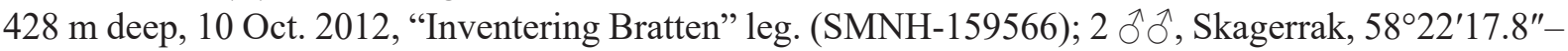
$19.4^{\prime \prime} \mathrm{N}, 10^{\circ} 23^{\prime} 50.8^{\prime \prime}-24^{\prime} 03.2^{\prime \prime} \mathrm{E}$, soft bottom 351-387 m deep, 10 Oct. 2012, "Inventering Bratten" leg. (SMNH-159567).

\section{Description}

\section{Adult}

Body cylindrical, posteriorly tapering in the tail region, straight or curved upon fixation. Cuticle coarsely annulated along entire body, except for smooth anterior end and terminal part of tail; annules 2-2.5 $\mu \mathrm{m}$ wide at mid-body region; longitudinal striation not observed under light microscope. Somatic setae present on tail. Labial region bluntly rounded. Cuticularised plate underlying cephalic cuticle around amphid absent. Inner and outer labial sensilla not seen. Cephalic sensilla papilliform, equal to 0.1 labial region diameter in length, their bases are located 3.5-4 $\mu \mathrm{m}$ from anterior end. Amphids similar in shape and size between sexes: amphidial fovea an inverted U-shape with dorsal branch longer than ventral branch. Narrow space between amphidial branches (amphidial shield) cuticularised with crenated edge. Stoma very small, its cuticularised lining uniform with lining of the pharynx. Pharynx distinctly subdivided into anterior corpus and posterior postcorpus; corpus cylindrical or slightly fusiform, muscular; postcorpus consists of anterior narrow non-muscular isthmus and pear-shaped glandular basal swelling. Pharyngeal gland nuclei and orifices indistinct. Nerve ring surrounding isthmus. Secretoryexcretory system present; secretory-excretory pore located along ventral body line opposite to basal pharyngeal swelling; secretory-excretory duct very short, leading from pore to ampulla; renette cell obscure. Tail subcylindrical with bluntly rounded terminus. Caudal glands opening via three separate openings, spinneret absent.

\section{Female}

Reproductive system didelphic, amphidelphic, reflexed; ovary branches symmetrical. Anterior ovary situated to either right or left of intestine; posterior ovary situated to left of intestine. Vulva located immediately posterior to mid-body. Vagina straight, 0.3 of vulval body diameter, with thick walls and 

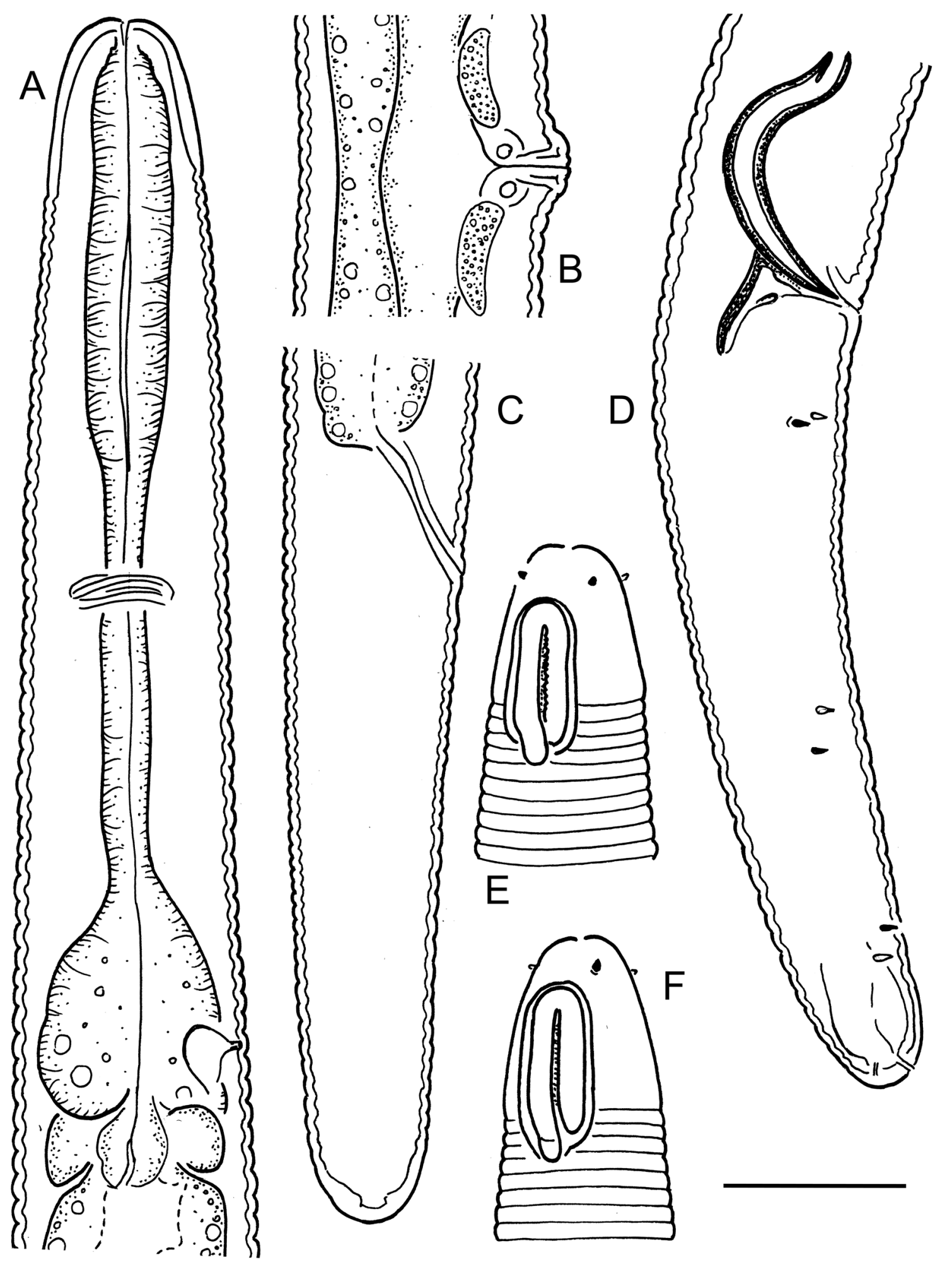

Fig. 7. Diplopeltoides nudus (Gerlach, 1956). A. Female pharyngeal region, optical median section. B. Vulval region. C. Female tail. D. Male tail. E. Female anterior end, surface view. F. Male anterior end, surface view. Scale bar $=20 \mu \mathrm{m}$. 
Table 4. Measurements (in $\mu \mathrm{m}$ ) of Diplopeltoides nudus (Gerlach, 1956), presented as mean and (range) for males and each female individual measurement separated with a semicolon.

\begin{tabular}{|c|c|c|}
\hline Sex & Female & Male \\
\hline Number of specimens & 2 & 3 \\
\hline Body length & $1135 ; 1004$ & $1179(1152-1225)$ \\
\hline Body diameter (BD) & $26 ; 27$ & $23(21-25)$ \\
\hline Pharynx length & $121 ; 117$ & $119(114-125)$ \\
\hline Tail length & $72 ; 71$ & $81(76-90)$ \\
\hline Anal body diameter (ABD) & $19 ; 18$ & $21(21-22)$ \\
\hline $\mathrm{a}$ & $43.3 ; 36.7$ & $51.4(45.9-59.7)$ \\
\hline $\mathrm{b}$ & $9.4 ; 8.6$ & $9.9(9.8-10.2)$ \\
\hline $\mathrm{c}$ & $15.8 ; 14.2$ & $14.6(13.6-15.2)$ \\
\hline$c^{\prime}$ & $3.7 ; 3.9$ & $3.8(3.5-4.2)$ \\
\hline $\mathrm{V}$ or $\mathrm{T}(\%)$ & $54.7 ; 54.3$ & $48.7(47.9-49.5)$ \\
\hline Labial region diameter & $12.0 ; 10.5$ & $10.8(10.5-11.0)$ \\
\hline Cephalic setae length & $1.5 ; 1.5$ & $1.0(1.0-1.5)$ \\
\hline Amphid from anterior end & $5.5 ; 5.5$ & $5.8(5.0-7.0)$ \\
\hline Dorsal amphid branch length & $18.5 ; 17.0$ & $18.9(16.5-20.0)$ \\
\hline Ventral amphid branch length & $16.0 ; 14.5$ & 17.3 \\
\hline Amphid width & $6.0 ; 6.0$ & $6.9(6.0-7.5)$ \\
\hline Nerve ring from anterior end & $65 ; 63$ & $65(64-66)$ \\
\hline $\begin{array}{l}\text { Nerve ring from anterior end as \% of } \\
\text { pharynx length }\end{array}$ & $54 ; 53$ & $54(53-55)$ \\
\hline Secretory-excretory pore from ant. end & $111 ; 102$ & 108 \\
\hline $\begin{array}{l}\text { Secretory-excretory pore from ant. end } \\
\text { as } \% \text { of pharynx length }\end{array}$ & $92 ; 86$ & 86 \\
\hline Anterior gonad length (to flexure) & $124 ; 114$ & - \\
\hline Posterior gonad length (to flexure) & $152 ; 90$ & - \\
\hline Vagina or spicules length & $9 ; 9$ & $37(35-38)$ \\
\hline Rectum or gubernaculum length & $17 ; 12$ & $10(9-11)$ \\
\hline Vagina length / BD & $0.3 ; 0.3$ & - \\
\hline Rectum or spicules length / ABD & $0.9 ; 0.6$ & $1.7(1.6-1.8)$ \\
\hline
\end{tabular}

developed sphincter muscle at its proximal part; pars refringens vaginae absent. Intrauterine egg not seen; sperm is visible in the uterus. Rectum short, $0.6-0.9$ of the corresponding body diameter long.

\section{Male}

Reproductive system diorchic, both testes outstretched. Spicules paired and symmetrical, strongly curved, with dorsally bent manubrium and subcylindrical, gradually narrowing shaft. Gubernaculum plate-like, with a pair of strong closely set caudal apophyses. Caudal setae present, arranged in subventral and subdorsal rows but difficult to observe and count. 


\section{Remarks}

The recently collected population of $D$. nudus is similar to the type specimens in general morphology and measurements, including the characteristic spicule shape, except for the somewhat longer spicules (35-38 $\mu \mathrm{m}$ vs $29 \mu \mathrm{m}$ in type specimens) and the presence of gubernaculum apophyses (vs absent in type specimens). As noted in the redescription of $D$. bulbosus, gubernaculum apophyses may be indistinct or absent in some specimens and should not be used as the sole diagnostic character.

Diplopeltoides pumilus (Vincx \& Gourbault, 1992) comb. nov. Fig. 8; Table 5

\section{Diagnosis}

Diplopeltoides pumilus is characterised by by a body of $0.43-0.58 \mathrm{~mm}$ long; cuticle with longitudinal striation; cuticularised plate absent; cephalic sensilla setiform, $2-3 \mu \mathrm{m}$ long; amphidial fovea an inverted U-shape, $8-17 \mu \mathrm{m}$ long and 8-11 $\mu \mathrm{m}$ wide in female and 13-19 $\mu \mathrm{m}$ long and $8-9 \mu \mathrm{m}$ wide in male; narrow space between amphidial branches not ornamented; secretory-excretory pore indistinct; tail conoid; testes opposed; spicules 24-27 $\mu \mathrm{m}$ long, strongly curved, with weakly defined manubrium and conoid shaft; gubernaculum plate-like, without apophyses.

\section{Material examined}

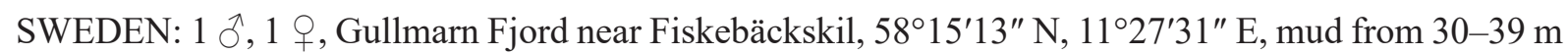

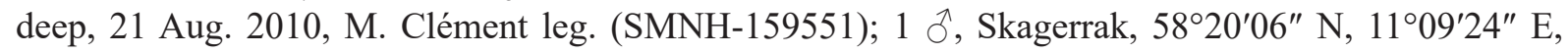
muddy sediment from 53 m deep, 9 Aug. 2011, O. Holovachov leg. (SMNH-159549); 2 우, Gullmarn Fjord near Fiskebäckskil, 58 ${ }^{\circ} 15^{\prime} 09^{\prime \prime} \mathrm{N}, 11^{\circ} 27^{\prime} 54^{\prime \prime} \mathrm{E}$, muddy sand from 8-15 m deep, 11 Aug. 2011, O. Holovachov leg. (SMNH-159550).

\section{Description}

\section{Adult}

Body cylindrical, posteriorly tapering in tail region, straight or curved upon fixation. Cuticle coarsely annulated along entire body, except for smooth anterior end (annulation starts at level of anterior $1 / 4$ of amphid) and terminal part of tail; annules $2.5 \mu \mathrm{m}$ wide at mid-body region; longitudinal striation is distinct under light microscope, covers annules over entire body length. Somatic setae present on tail. Labial region bluntly rounded. Cuticularised plate underlying cephalic cuticle around amphid absent. Inner and outer labial sensilla not seen. Cephalic sensilla setiform, equal to 0.2-0.3 labial region diameters in length, their bases are located 2-5 $\mu \mathrm{m}$ from anterior end. Amphids similar in shape and size between sexes: amphidial fovea an inverted U-shape with branches equal in length. Narrow space between amphidial branches (amphidial shield) not cuticularised and not ornamented. Stoma very small, its cuticularised lining is uniform with lining of pharynx. Pharynx distinctly subdivided into anterior corpus and posterior postcorpus; corpus cylindrical or slightly fusiform, muscular; postcorpus consists of anterior narrow non-muscular isthmus and pear-shaped glandular basal swelling. Pharyngeal gland nuclei and orifices indistinct. Nerve ring surrounding isthmus. Secretory-excretory system indistinct. Tail conoid. Caudal glands opening via three separate openings, spinneret absent.

\section{Female}

Reproductive system didelphic, amphidelphic, reflexed; ovary branches symmetrical. Anterior ovary situated to either right or left of intestine; posterior ovary situated to either left or right of intestine. Vulva located immediately posterior to mid-body. Vagina straight, 0.2 of the vulval body diameter, with thick walls; pars refringens vaginae absent. Intrauterine egg not seen; sperm is sometimes visible in the uterus. Rectum short, $0.7-0.8$ of corresponding body diameter long. 




Fig. 8. Diplopeltoides pumilus (Vincx \& Gourbault, 1992) comb. nov. A. Female pharyngeal region, optical median section. B. Female tail. C. Female anterior end, surface view. D. Male tail. E. Male anterior end, surface view. F. Vulval region. Scale bar $=20 \mu \mathrm{m}$. 
Table 5. Measurements (in $\mu \mathrm{m}$ ) of Diplopeltoides pumilus (Vincx \& Gourbault, 1992) comb. nov., presented as mean and (range) for females and and each male individual measurement separated with a semicolon; "?" indicates that the character can not be observed or measured.

\begin{tabular}{lcc}
\hline Sex & Female & Male \\
\hline Number of specimens & 3 & 2 \\
Body length & $543(520-564)$ & $504 ; 578$ \\
Body diameter (BD) & $36(32-38)$ & $22 ; 28$ \\
Pharynx length & $115(107-121)$ & $121 ; 119$ \\
Tail length & $81(77-85)$ & $77 ; 91$ \\
Anal body diameter (ABD) & $20(19-21)$ & $17 ; 21$ \\
a & $15.3(14.6-16.4)$ & $22.8 ; 20.4$ \\
b & $4.7(4.6-4.9)$ & $4.2 ; 4.8$ \\
c & $6.7(6.6-6.8)$ & $6.5 ; 6.3$ \\
c' & $4.0(4.0-4.1)$ & $4.5 ; 4.4$ \\
V or T (\%) & $52.4(52.1-52.9)$ & $? ; 44.5$ \\
Labial region diameter & $10.4(10.0-12.0)$ & $8.0 ; 10.5$ \\
Cephalic setae length & $2.5(2.0-3.0)$ & $3.0 ; 2.0$ \\
Amphid from anterior end & $6.7(6.0-7.0)$ & $6.0 ; 5.0$ \\
Dorsal amphid branch length & $16.3(16.0-16.5)$ & $19.0 ; 16.0$ \\
Ventral amphid branch length & $16.1(15.0-16.5)$ & $19.0 ; 16.0$ \\
Amphid width & $9.0(7.5-10.5)$ & $9.0 ; 8.0$ \\
Nerve ring from anterior end & $65(62-68)$ & $65 ; 68$ \\
Nerve ring from anterior end as \% of & $58(56-58)$ & $53 ; 57$ \\
pharynx length & $107(95-130)$ & - \\
Anterior gonad length (to flexure) & $97(77-119)$ & - \\
Posterior gonad length (to flexure) & $8(7-9)$ & $24 ; 26$ \\
Vagina or spicules length & $14(14-15)$ & $1.4 ; 1.3$ \\
Rectum or gubernaculum length & 0.2 & \\
Vagina length / BD & $0.7(0.7-0.8)$ & \\
Rectum or spicules / ABD & & \\
\hline
\end{tabular}

\section{Male}

Reproductive system diorchic, testes opposed: anterior testis outstretched and posterior testis reflexed. Spicules paired and symmetrical, strongly curved, with weakly defined manubrium and conoid shaft. Gubernaculum plate-like, without apophyses. Caudal setae present, arranged in subventral and subdorsal rows but difficult to observe and count.

\section{Remarks}

The recently collected population of $D$. pumilus is similar to the type specimen in general morphology and measurements, structure of cuticle and anterior end, differing only in the larger body size $(0.50$ $0.58 \mathrm{~mm}$ vs $0.29 \mathrm{~mm}$ in the type specimen), the longer amphid (16-19 $\mu \mathrm{m}$ vs $10 \mu \mathrm{m}$ in the type specimen), 
the longer tail ( $c^{\prime}=4.0-4.5 \mathrm{vs} \mathrm{c}{ }^{\prime}=3.5$ in the type specimen) and the longer spicules $(24-26 \mu \mathrm{m}$ vs $19 \mu \mathrm{m}$ in the type specimen). It is also similar to $D$. holovachovi from the Sea of Japan in general morphology, structure of cuticle and anterior end, except for the longer body $(0.50-0.58 \mathrm{~mm}$ vs $0.43-0.50 \mathrm{~mm}$ in D. holovachovi) and less pronounced sexual dimorphism in the shape of the amphid (more elongated in females vs more rounded in females from the type population).

Diplopeltoides linkei Jensen, 1991

Fig 9. A-C; Table 6

\section{Diagnosis}

Diplopeltoides linkei is characterised by a body of $0.48-0.63 \mathrm{~mm}$ long; cuticle with longitudinal striation; cuticularised plate underlying cephalic cuticle around amphid present; cephalic sensilla setiform, $2-3 \mu \mathrm{m}$ long; amphidial fovea an inverted U-shape, 14-19 $\mu \mathrm{m}$ long and 7-8 $\mu \mathrm{m}$ wide; narrow space between amphidial branches not ornamented; secretory-excretory pore located opposite to isthmus; tail conoid; testes opposed; spicules 29-36 $\mu \mathrm{m}$ long, strongly curved, with round manubrium and subcylindrical shaft; gubernaculum plate-like, without apophyses.

\section{Material examined}


deep, 11 Oct. 2012, "Inventering Bratten" leg. (SMNH-159564); 1 ô, Gullmarn Fjord near Lysekil, $58^{\circ} 15.73^{\prime} \mathrm{N}, 11^{\circ} 26.10^{\prime} \mathrm{E}$, mud from $53 \mathrm{~m}$ deep, 14 Aug. 2014, O. Holovachov and U. Jondelius leg. (SMNH-159565).

\section{Description}

\section{Adult male}

Body cylindrical, posteriorly tapering in tail region, weakly curved upon fixation. Cuticle coarsely annulated along entire body, except for smooth anterior end (annulation starts at level of posterior $1 / 4$ of amphid) and terminal part of tail; annules 3-4 $\mu \mathrm{m}$ wide at mid-body region; longitudinal striation is distinct under the light microscope, covers annules over entire body length. Somatic setae not observed. Labial region bluntly rounded. Cuticularised plate underlying cephalic cuticle around amphid strongly developed, extending from level of anteriormost edge of amphid to level of posteriormost edge, 18.5-19 $\mu \mathrm{m}$ long and 13-14.5 $\mu \mathrm{m}$ wide at base; cuticular plates connected with each other on ventral and on dorsal sides. Inner and outer labial sensilla not seen. Cephalic sensilla setiform, equal to 0.3 labial region diameters in length, their bases are located 3.5-4 $\mu \mathrm{m}$ from anterior end. Amphidial fovea an inverted U-shape with ventral branch longer than dorsal branch. Narrow space between amphidial branches (amphidial shield) not cuticularised and not ornamented. Stoma very small, its cuticularised lining is uniform with lining of the pharynx. Pharynx distinctly subdivided into anterior corpus and posterior postcorpus; corpus cylindrical or slightly fusiform, muscular; postcorpus consists of anterior narrow non-muscular isthmus and pear-shaped glandular basal swelling. Pharyngeal gland nuclei large, orifices of pharyngeal glands indistinct. Nerve ring surrounding isthmus. Secretory-excretory system present; secretory-excretory pore located along ventral body line opposite to isthmus; secretory-excretory duct very short; renette cell not observed. Tail conoid. Caudal glands opening via three separate openings, spinneret absent. Reproductive system diorchic, testes opposed: anterior testis outstretched and posterior testis reflexed. Spicules paired and symmetrical, strongly curved, with round manubrium and subcylindrical shaft. Gubernaculum plate-like, without apophyses. Caudal setae: two subventral pairs and single subdorsal.

\section{Female}

Not found. 




Fig. 9. A-C. Diplopeltoides linkei Jensen, 1991, male. A. Anterior end, surface view. B. Pharyngeal region, optical median section. C. Tail. - D-G. Diplopeltoides longicaudatus sp. nov., male. D. Tail. E. Anterior end, surface view. F. Pharyngeal region, optical median section. G. Cloacal region. Scale bar: A-C, $\mathrm{E}-\mathrm{G}=20 \mu \mathrm{m}, \mathrm{D}=40 \mu \mathrm{m}$. 
Table 6. Measurements (in $\mu \mathrm{m}$ ) of Diplopeltoides linkei Jensen, 1991, Diplopeltoides longicaudatus sp. nov. and Diplopeltoides grandis sp. nov. (for D. linkei: each male individual measurement separated with a semicolon; "?" indicates that the character can not be observed or measured).

\begin{tabular}{|c|c|c|c|}
\hline Species & linkei & longicaudatus sp. nov. & grandis sp. nov. \\
\hline Sex & male & holotype male & holotype female \\
\hline Number of specimens & 2 & 1 & 1 \\
\hline Body length & $639 ; 623$ & 1031 & 2063 \\
\hline Body diameter (BD) & $28 ; 32$ & 20 & 44 \\
\hline Pharynx length & $128 ; 133$ & 67 & 131 \\
\hline Tail length & $86 ; 81$ & 93 & 125 \\
\hline Anal body diameter (ABD) & $24 ; 24$ & 15 & 30 \\
\hline $\mathrm{a}$ & $23.1 ; 19.6$ & 51.5 & 47.5 \\
\hline $\mathrm{b}$ & $5.0 ; 4.7$ & 15.4 & 15.7 \\
\hline $\mathrm{c}$ & $7.4 ; 7.7$ & 11.1 & 16.5 \\
\hline$c^{\prime}$ & $3.7 ; 3.3$ & 6.4 & 4.2 \\
\hline $\mathrm{V}$ or $\mathrm{T}(\%)$ & $52.5 ; 53.6$ & 38.1 & 58.7 \\
\hline Labial region diameter & $10.0 ; 10.5$ & 5.0 & 14.0 \\
\hline Cephalic setae length & $3.0 ; 3.0$ & 13.0 & 18.5 \\
\hline Amphid from anterior end & $6.0 ; 7.0$ & 8.0 & 12.5 \\
\hline Dorsal amphid branch length & $17.0 ; 18.5$ & 6.0 & 30.0 \\
\hline Ventral amphid branch length & $18.0 ; 19.0$ & 5.0 & 25.0 \\
\hline Amphid width & $7.5 ; 8.0$ & 4.0 & 14.0 \\
\hline Nerve ring from anterior end & $75 ; 81$ & $?$ & 97 \\
\hline $\begin{array}{l}\text { Nerve ring from anterior end as } \% \text { of } \\
\text { pharynx length }\end{array}$ & $59 ; 61$ & $?$ & 74 \\
\hline Secretory-excretory pore from ant. end & 95 & 53 & 99 \\
\hline $\begin{array}{l}\text { Secretory-excretory pore from ant. end } \\
\text { as \% of pharynx length }\end{array}$ & 74 & 79 & 76 \\
\hline Anterior gonad length (to flexure) & - & - & 310 \\
\hline Posterior gonad length (to flexure) & - & - & 262 \\
\hline Vagina or spicules length & $32 ; 36$ & $27 / 31$ & 10 \\
\hline Rectum or gubernaculum length & $7 ; 4$ & $?$ & 18 \\
\hline Vagina length / BD & - & - & 0.2 \\
\hline Rectum or spicules / ABD & $1.4 ; 1.5$ & $1.9 / 2.1$ & 0.6 \\
\hline
\end{tabular}

\section{Remarks}

The recently collected population of $D$. linkei is similar to the type specimens from the Norwegian Sea in general morphology, structure of cuticle and anterior end, except for the somewhat longer body $(0.62-0.63 \mathrm{~mm}$ vs $0.48-0.50 \mathrm{~mm}$ in type specimens) and longer spicules $(32-36 \mu \mathrm{m}$ vs $29 \mu \mathrm{m})$. 


\section{Diplopeltoides longicaudatus sp. nov. urn:1sid:zoobank.org:act:048C4270-0463-408E-89EE-8D6B2A8E61C3}

Fig. 9 D-G; Table 6

\section{Diagnosis}

Diplopeltoides longicaudatus sp. nov. is characterised by a body of $1.03 \mathrm{~mm}$ long; cuticle without longitudinal striation; cuticularised plate underlying cephalic cuticle around amphid present; cephalic sensilla setiform, $13 \mu \mathrm{m}$ long; amphidial fovea an inverted U-shape, $6 \mu \mathrm{m}$ long and $4 \mu \mathrm{m}$ wide; narrow space between amphidial branches not ornamented; excretory pore indistinct; tail elongate conoid; spicules unequal in size, $27-31 \mu \mathrm{m}$ long, arcuate, with small ovoid manubrium and subcylindrical shaft; gubernaculum absent; midventral precloacal cuticular ridge present.

\section{Etymology}

The specific epithet refers to the characteristic long tail in this species.

\section{Type material}

\section{Holotype}

SWEDEN: ${ }^{\top}$, Skagerrak, $58^{\circ} 20.32^{\prime}-20.38^{\prime} \mathrm{N}, 1^{\circ} 12.73^{\prime}-12.68^{\prime}$ E, coarse shell sand 14-17 m deep, 19 Aug. 2014, O. Holovachov and U. Jondelius leg. (SMNH Type-8843).

\section{Description}

\section{Adult male}

Body cylindrical, posteriorly tapering in tail region, strongly ventrally curved upon fixation. Cuticle finely annulated along entire body, except for smooth anterior end and terminal part of tail; annules $1.5 \mu \mathrm{m}$ wide at mid-body region; longitudinal striation not observed under light microscope. Somatic setae indistinct. Labial region truncate conoid; lips fused. Cuticularised plate underlying cephalic cuticle around amphid weakly developed, extending from level of cephalic setae bases to posteriormost edge of amphid, $9 \mu \mathrm{m}$ long and $7.5 \mu \mathrm{m}$ wide at base; cuticular plates connected with each other on ventral and on dorsal sides. Inner and outer labial sensilla not observed. Cephalic sensilla setiform, equal to 2.7 labial region diameters in length, their bases are located $1.5 \mu \mathrm{m}$ from anterior end. Amphidial fovea an inverted U-shape with dorsal branch longer than ventral branch. Narrow space between amphidial branches (amphidial shield) not cuticularised and not ornamented. Stoma very small, its cuticularised lining uniform with lining of the pharynx. Pharynx distinctly subdivided into anterior corpus and posterior postcorpus; corpus fusiform, muscular; postcorpus consists of anterior narrow non-muscular isthmus and weakly developed basal swelling. Pharyngeal gland nuclei and orifices indistinct. Nerve ring not observed. Secretory-excretory system not observed. Tail elongate conoid. Caudal glands opening via three separate openings, spinneret absent. Reproductive system obscure. Spicules paired and somewhat unequal in size, arcuate, with small ovoid manubrium and subcylindrical shaft. Gubernaculum absent. Midventral cuticular ridge extending anteriorly from about level of middle of spicules for $150 \mu \mathrm{m}$ towards mid-body. Caudal setae not observed.

\section{Female}

Not found.

\section{Remarks}

Diplopeltoides longicaudatus sp. nov. is unique among known species of Diplopeltoides in having a precloacal cuticular ridge in males - a feature found in several species of the related genus Tarvaia Allgén, 1934 (Holovachov et al. 2012). In having a cuticularised plate underlying the cuticle of the anterior end, the new species is similar to D. ornatus, D. linkei, D. axayacatli, D. grandis sp. nov. and D. suecicus 
sp. nov. The new species further differs from $D$. ornatus and $D$. linkei in the structure of cuticle (smooth vs striated under the light microscope); a body length of $1.03 \mathrm{~mm}$ vs $0.43-0.63 \mathrm{~mm}$, the length of the cephalic setae $(13 \mu \mathrm{m}$ vs $2-4 \mu \mathrm{m})$ and tail (c' $=6.4$ vs 3.2-4.2); it differs from $D$. axayacatli, $D$. grandis sp. nov. and D. suecicus sp. nov. in having no interamphideal shield (vs present and ornamented).

Diplopeltoides grandis sp. nov. urn:1sid:zoobank.org:act:1954B3FA-0622-45CD-AF8C-EA3954F9EE3C

Figs 10, 11B-C; Table 6

\section{Diagnosis}

Diplopeltoides grandis sp. nov. is characterised by a body of $2.06 \mathrm{~mm}$ long; cuticle with longitudinal striation; cuticularised plate underlying cephalic cuticle around amphid present; cephalic sensilla setiform, $18.5 \mu \mathrm{m}$ long; amphidial fovea an inverted U-shape, $30 \mu \mathrm{m}$ long and $14 \mu \mathrm{m}$ wide; wide space between amphidial branches punctate; excretory pore indistinct; tail conoid.

\section{Etymology}

The specific epithet refers to the large body size in this species.

\section{Type material}

\section{Holotype}

SWEDEN: + , Skagerrak, $58^{\circ} 20.32^{\prime}-20.38^{\prime} \mathrm{N}, 1^{\circ} 12.73^{\prime}-12.68^{\prime} \mathrm{E}$, coarse shell sand $14-17 \mathrm{~m}$ deep, 19 Aug. 2014, O. Holovachov and U. Jondelius leg. (SMNH Type-8844).

\section{Description}

\section{Adult female}

Body cylindrical, posteriorly tapering in tail region, curved upon fixation. Cuticle coarsely annulated along entire body, except for smooth anterior end and terminal part of the tail; annules $3 \mu \mathrm{m}$ wide at mid-body region; longitudinal striation is distinct under light microscope, covers annules over entire body length. Somatic setae indistinct. Labial region truncate conoid, lips fused. Cuticularised plate underlying cephalic cuticle around amphid strongly developed, extending from the level of cephalic setae bases to the posteriormost edge of amphid, $38 \mu \mathrm{m}$ long and $23 \mu \mathrm{m}$ wide at base; cuticular plates connected with each other on ventral and on dorsal sides. Inner labial sensilla not seen, outer labial sensilla small papilliform, located on the anterior surface of lips. Cephalic sensilla setiform, equal to 1.4 labial region diameters in length, their bases located $4 \mu \mathrm{m}$ from anterior end. Amphidial fovea an inverted U-shape with dorsal branch longer than ventral branch. Wide space between amphidial branches (amphidial shield) heavily cuticularised and punctate. Stoma very small, its cuticularised lining uniform with lining of the pharynx. Pharynx distinctly subdivided into anterior corpus and posterior postcorpus; corpus fusiform, muscular; postcorpus consists of anterior narrow non-muscular isthmus and pear-shaped glandular basal swelling. Pharyngeal gland nuclei and orifices indistinct. Nerve ring surrounding isthmus. Secretory-excretory system not observed. Tail conoid. Caudal glands opening via three separate openings, spinneret absent. Reproductive system didelphic, amphidelphic, reflexed; ovary branches symmetrical. Anterior ovary situated to right of intestine; posterior ovary situated to left of intestine. Vulva a transverse slit, located immediately posterior to mid-body. Vagina straight, 0.2 of the vulval body diameter, with thick walls; pars refringens vaginae absent. Intrauterine egg or sperm not observed. Rectum short, 0.6 of the corresponding body diameter long.

\section{Male}

Not found. 


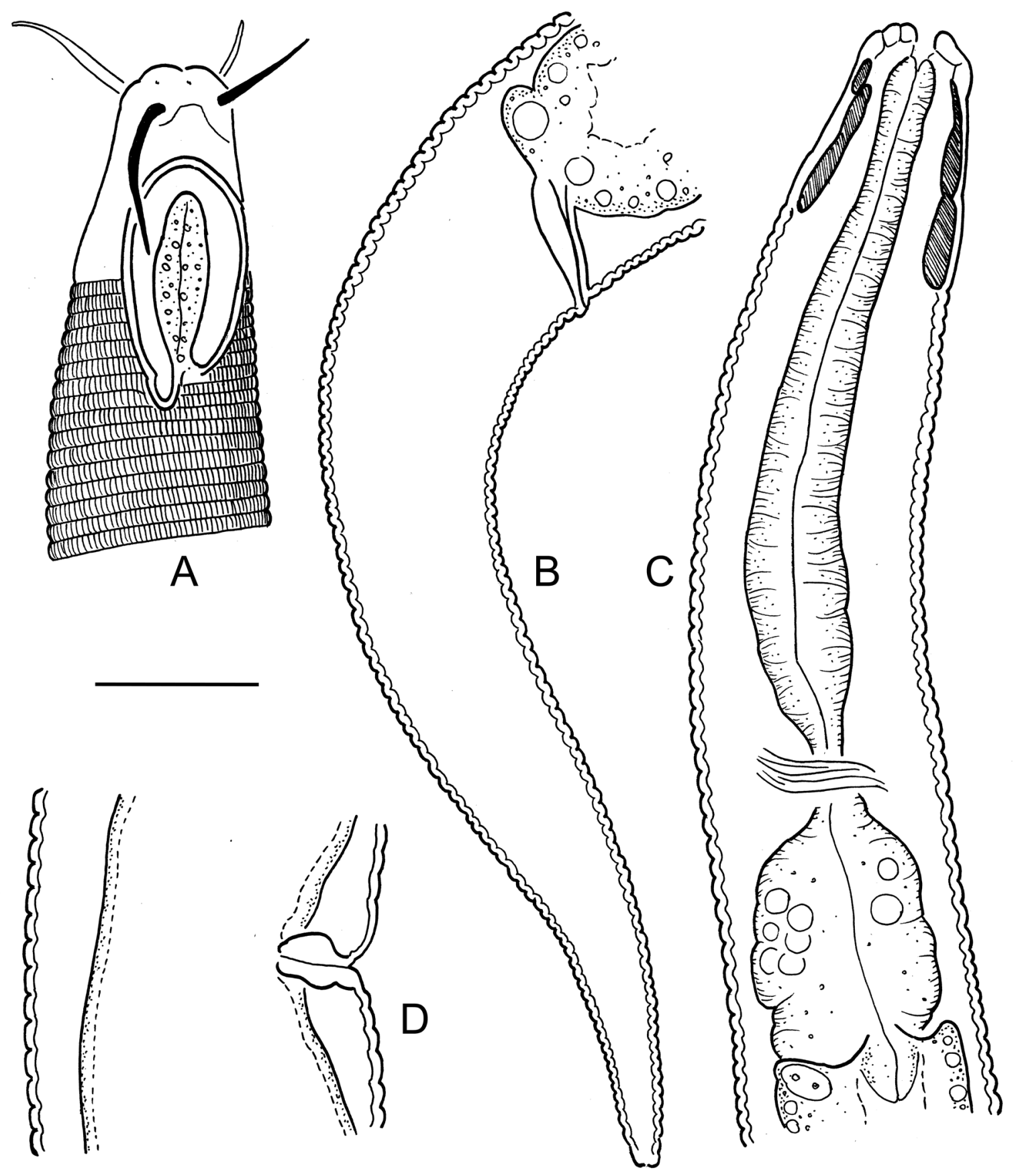

Fig. 10. Diplopeltoides grandis sp. nov. A. Female anterior end, surface view. B. Female tail. C. Female pharyngeal region, optical median section. D. Vulval region. Scale bar $=20 \mu \mathrm{m}$. 


\section{Remarks}

Diplopeltoides grandis sp. nov. is most similar to $D$. axayacatli in having a relatively large body size, a distinctly striated cuticle and a developed cuticularised plate. The new species differs from $D$. axayacatli in the shape of the amphid (loop-shaped, with parallel branches vs hook-shaped, with one of the branches bent inward, in D. axayacatli) and its size $(30 \times 14 \mu \mathrm{m}$ vs $11-15 \times 8-9 \mu \mathrm{m}$ in D. axayacatli $)$.

\section{Key to species of Diplopeltoides}

See Table 7 for additional diagnostic characters.

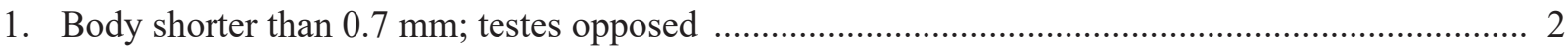

- Body longer than $0.8 \mathrm{~mm}$; testes outstretched ......................................................................... 4

2. Cuticularised plate present; annulation starts at the posterior $1 / 4^{\text {th }}$ of amphid .............................. 3

- Cuticularised plate absent; annulation starts at the anterior $1 / 4^{\text {th }}$ of amphid

D. pumilus (Vincx \& Gourbault, 1992) comb. nov.

3. Spicules $22 \mu \mathrm{m}$ long; gubernaculum triangular

D. ornatus (Gerlach, 1950)

- Spicules 29-36 $\mu \mathrm{m}$ long; gubernaculum plate-like D. linkei Jensen, 1991

4. Cuticlar annules with londitudinal striation distinctly visible under the light microscope 5

- Cuticular annules visually smooth under light microscope, longitudinal striation may be visible under scanning electron microscope

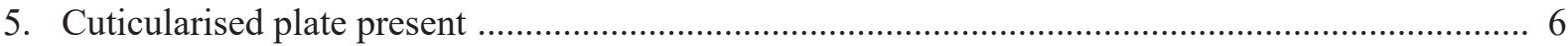

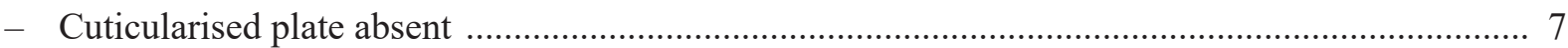

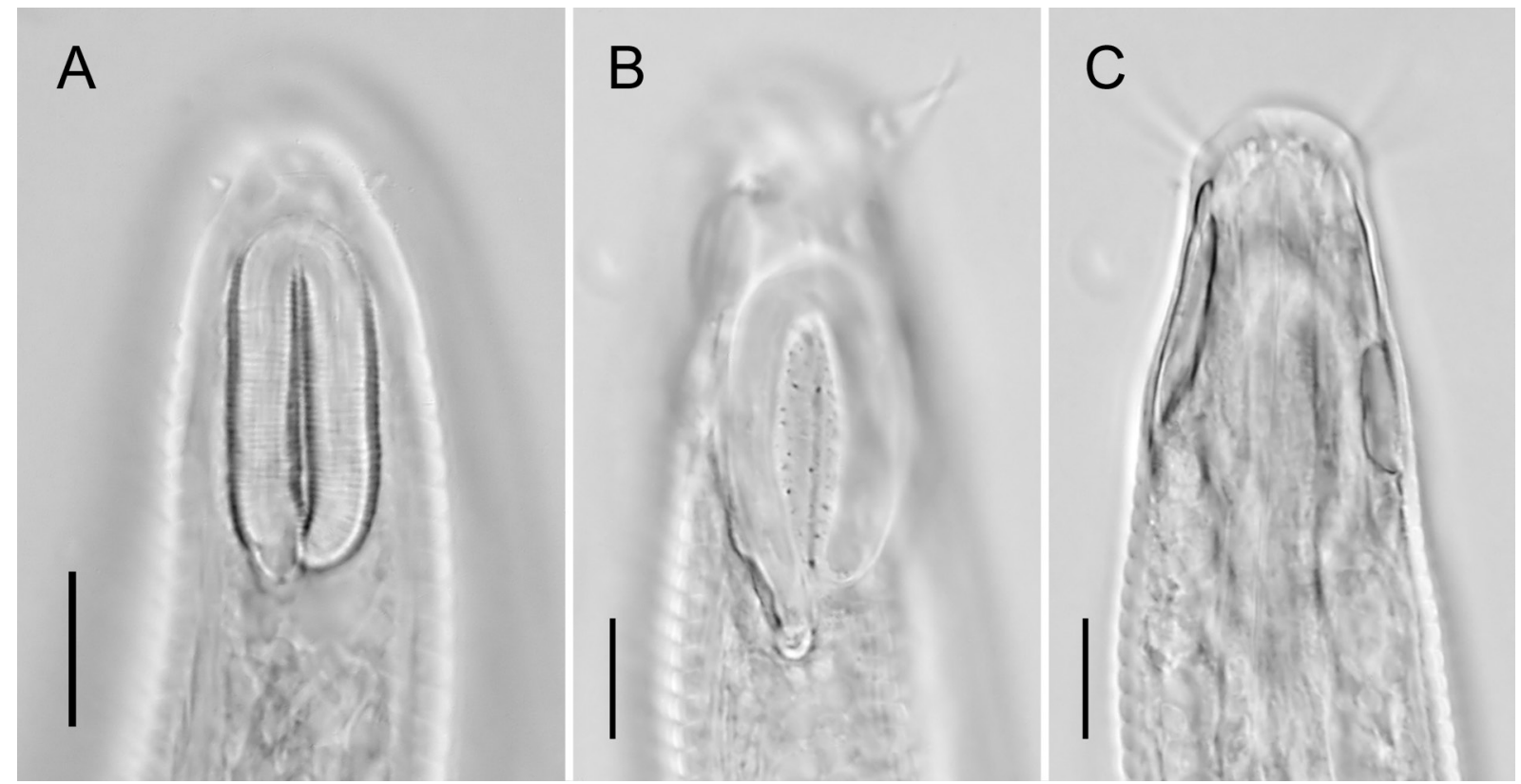

Fig. 11. Light microscopy images of anterior ends. A. Diplopeltoides bulbosus (Vitiello, 1972) comb. nov., female, amphid. - B-C. Diplopeltoides grandis sp. nov., holotype, female. B. Amphid. C. Cuticularised plate. Scale bars: A-C $=20 \mu \mathrm{m}$. 
6. Amphid hook-shaped

D. axayacatli Holovachov, Tandingan De Ley, Mundo-Ocampo, Gingold \& De Ley, 2009

- Amphid an inverted U-shaped D. grandis sp. nov.

7. Interamphideal shield crenate

D. santaclarae Holovachov, Tandingan De Ley, Mundo-Ocampo, Gingold \& De Ley, 2009

- Interamphideal shield smooth

8. Body $1.7 \mathrm{~mm}$ long; spicules $17 \mu \mathrm{m}$ long

D. striatus (Gerlach, 1956) comb. nov.

- Body 1.0-1.2 mm long; spicules $25 \mu \mathrm{m}$ long

D. pulcher (Vincx \& Gourbault, 1992)

9. Amphidial fovea with fine transverse striation

D. bulbosus (Vitiello, 1972) comb. nov.

- Amphidial fovea without fine transverse striation

10. Cuticular plate present

- Cuticular plate absent

11. Cephalic setae 4-6 $\mu \mathrm{m}$ long; amphid 14-21 $\mu \mathrm{m}$ long; precloacal ridge absent

D. suecicus sp. nov.

- Cephalic setae $13 \mu \mathrm{m}$ long; amphid $6 \mu \mathrm{m}$ long; precloacal ridge present

D. longicaudatus sp. nov.

12. Amphid with wide interamphideal area

- Amphid with narrow interamphideal area

13. Interamphideal area smooth, without ornamentation

- Interamphideal area punctated, areolated or crenated

14. Cephalic setae $17 \mu \mathrm{m}$ long

D. botulus (Wieser, 1959) comb. nov.

- Cephalic setae $5 \mu \mathrm{m}$ long

D. sundensis (Jensen, 1978)

15. Cephalic setae 12-18 $\mu \mathrm{m}$ long; amphid 21-26 $\mu \mathrm{m}$ long

D. paramastigia Holovachov, Tandingan De Ley, Mundo-Ocampo, Gingold \& De Ley, 2009

- Cephalic setae 6.5-8.5 $\mu \mathrm{m}$ long; amphid 40-45 $\mu \mathrm{m}$ long

D. mastigia Tchesunov, 1990

16. Cephalic setae longer than $10 \mu \mathrm{m}$

D. lucanicus (Boucher \& Helléouët, 1977) comb. nov.

- Cephalic setae shorter than $10 \mu \mathrm{m}$

17. Cephalic setae $3.5-7 \mu \mathrm{m}$ long

D. asetosus (Juario, 1974) comb. nov.

- Cephalic setae less than 1-2 $\mu \mathrm{m}$ long

18. Spicules with dorsally bent manubrium; amphid 17-28 $\mu \mathrm{m}$ long

- Spicules with straight manubrium; amphid 26-33 $\mu \mathrm{m}$ long

D. nudus (Gerlach, 1956)

D. anatolii (Voronov, 1982)

\section{Discussion}

When proposing the new genus Diplopeltoides, Gerlach (1962) traditionally did not provide a proper differential diagnosis for his new taxon, merely stating that the type species of the new genus, Diplopeltis ornatus, had "complicated cuticular structure and a ring-shaped cephalic capsule". The exact meaning of the phrase "complicated cuticular structure" is unclear and the utility of this character for a generic 


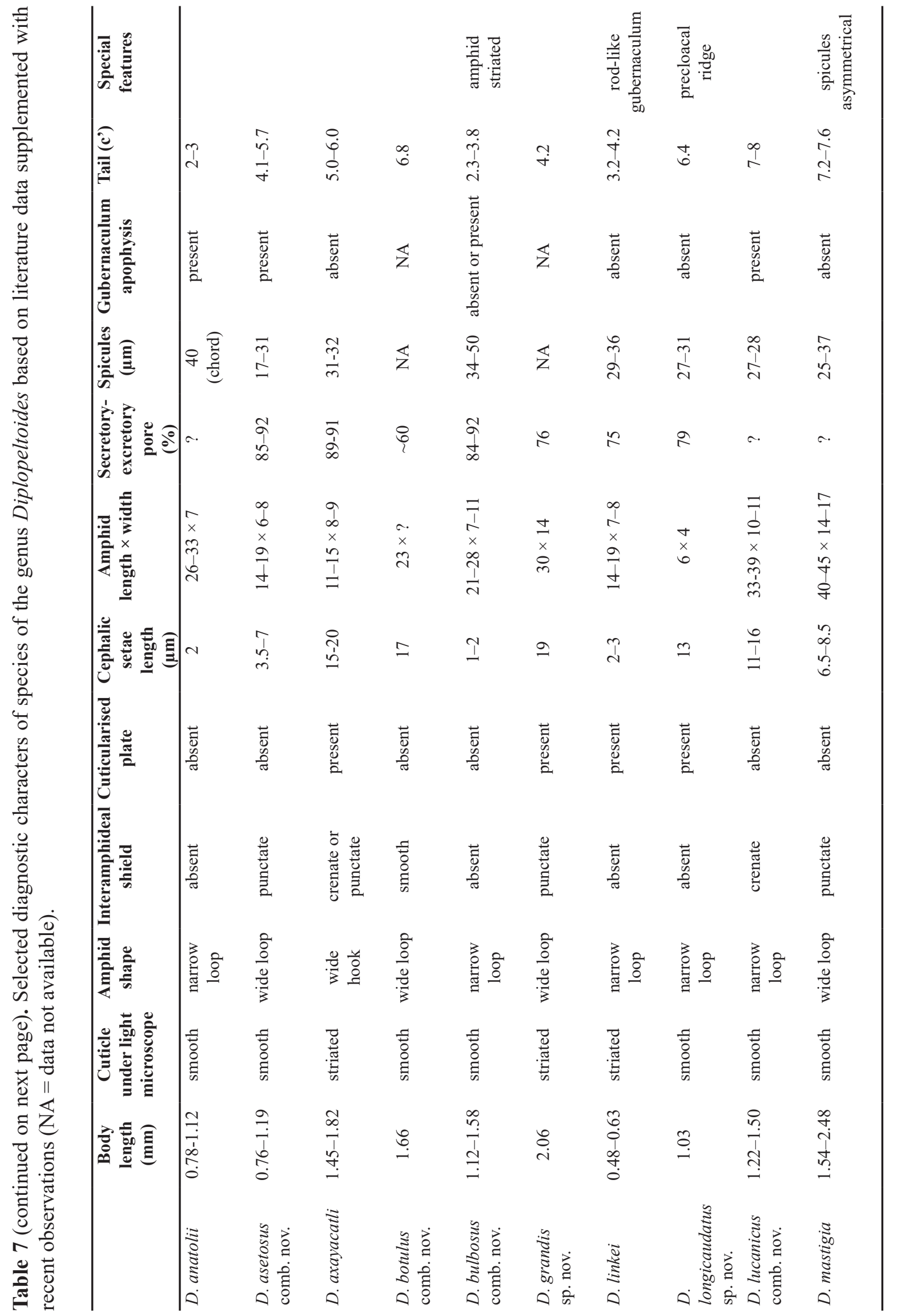




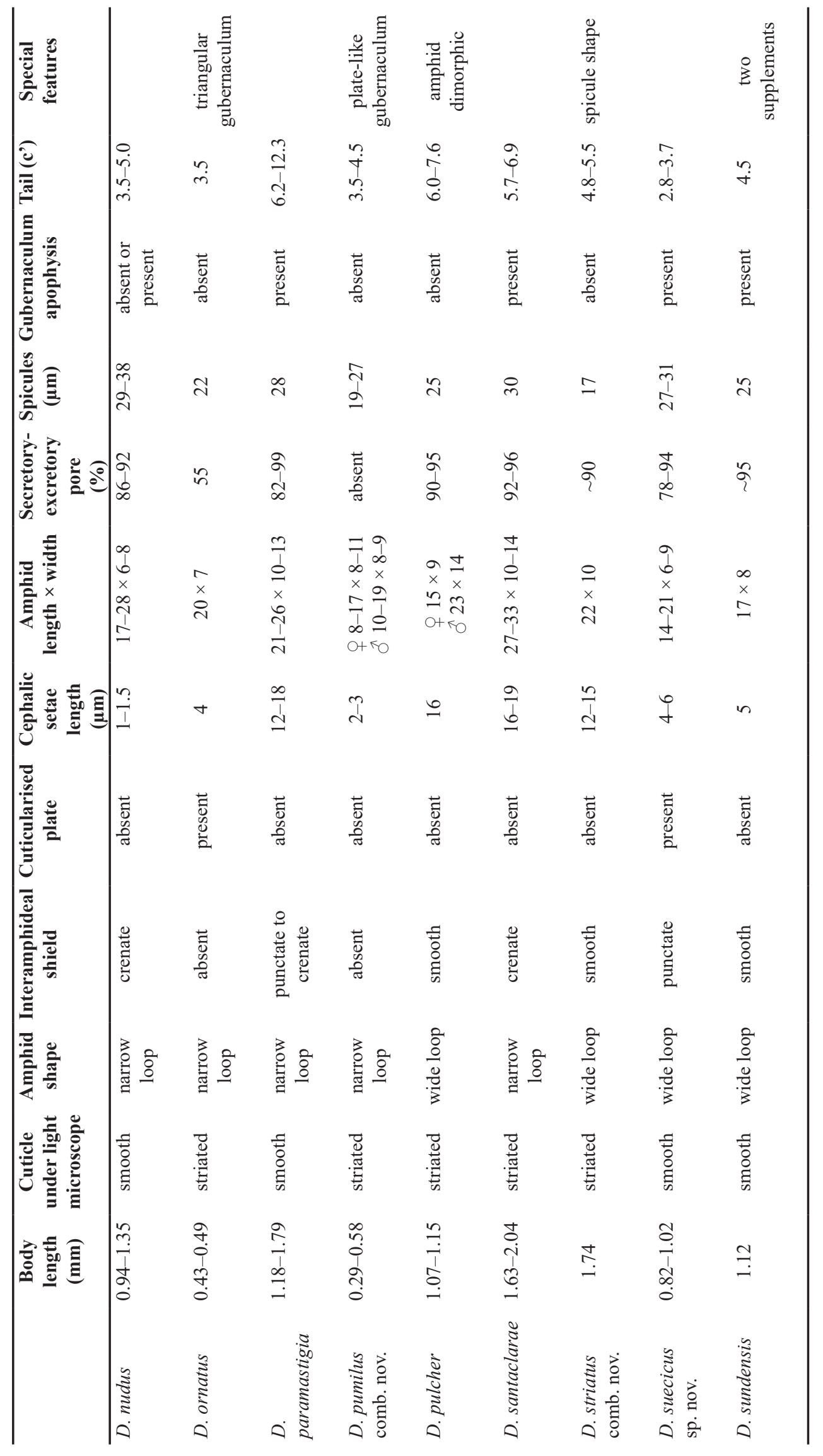


diagnosis is questionable. In the original description, the cuticle of $D$. ornatus is described as having a fine longitudinal striation (Gerlach 1950). The same character is typical of Diplopeltula striata (Gerlach 1956) and maintained in the description of the genus Diplopeltula (Gerlach 1962). None of the original distinguishing characters were mentioned by Lorenzen (1981), who removed the genus Diplopeltoides from the family Diplopeltidae based on the morphology of the female reproductive system (antidromously reflexed ovaries) as one of the main diagnostic characters. The other diagnostic character was the structure of the pharynx, with "thin walls and no muscle in the middle section" and a basal swelling. Tchesunov (1990) used these characters further to support the creation of the monotypic family Diplopeltoididae. He also suspected that many species of the genus Diplopeltula would be transferred to Diplopeltoides when new data on the morphology of the digestive and reproductive structures came to light. Subsequent publications (Tchesunov 2006; Holovachov et al. 2009) proved him to be correct.

The genus Diplopeltula was retained in the family Diplopeltidae by both Lorenzen (1981) and Tchesunov (1990); one of the diagnostic characters of this family being the presence of outstretched ovaries. The problem, however, is that the original description of the type species Diplopeltula breviceps Gerlach, 1950 does not include clear descriptions of the pharynx or of the female reproductive system - features that are used not only to distinguish Diplopeltoides from Diplopeltula, but also from the recently proposed Mudwigglus Leduc, 2013 (Leduc 2013). Thus, even though the majority of species currently placed in the genus Diplopeltula by Leduc (2017) are characterized by a cylindrical pharynx (with or without posterior bulb) and outstretched ovaries, both characters are unknown for the type species of the genus (Gerlach 1950) and cannot be used as diagnostic for the genus. By ignoring the female morphology in his descriptions, and not preserving any type material of his new species, S. Gerlach left marine nematology with a number of unresolved taxonomic issues, such as the taxonomic status of the genus Diplopeltula. Until new specimens of Diplopeltula breviceps are collected from the type locality and re-described in detail, the status of the genus Diplopeltula and its species will remain uncertain. The most logical approach would be to consider Diplopeltula breviceps a species inquirenda, consider Diplopeltula a genus inquirendum and transfer all other species currently placed in it into other well defined existing or newly proposed genera.

\section{Acknowledgments}

This research was supported by two grants from the Swedish Taxonomy Initiative: "Taxonomy and distribution of free-living nematodes of the order Plectida in Sweden" and "Systematics of Swedish free-living nematodes of the orders Desmodorida and Araeolaimida". Sampling in the Skagerrak was conducted using vessels ("Skagerak" and "Oscar von Sydow") and facilities of the Sven Lovén Centre for Marine Sciences in Kristineberg.

\section{References}

De Grisse A.T. 1969. Redescription ou modifications de quelques techniques utilisées dans l'étude des nématodes phytoparasitaires. Mededelingen Rijksfakulteit Landbouwwetenschappen Gent 34: 351-369.

Diesing K. M. 1861. Revision der Nematoden. Sitzungsberichte der Kaiserlichen Akademie der Wissenschaften, Mathematisch-Naturwissenschaftliche Classe 42: 595-736.

Fadeeva N. \& Mordukhovich V. 2013. Some new and poorly known nematode species from the Sea of Japan. Deep-Sea Research II 86-87: 119-123. https://doi.org/10.1016/j.dsr2.2012.07.044

Fonseca G. \& Bezerra T.N. 2014. 7.15 Order Araeolaimida De Coninck \& Schuurmans Stekhoven, 1933. In: Schmidt-Rhaesa A. (ed.) Handbook of Zoology. Gastrotricha, Cycloneuralia, Gnathifera. Volume 2: Nematoda: 467-486. de Gruyter, Berlin. 
Gerlach S.A. 1950. Die Diplopeltiden, eine Gruppe freilebender Nematoden. Kieler Meeresforschungen 7: $138-156$.

Gerlach S.A. 1956. Diagnosen neuer Nematoden aus der Kieler Bucht. Kieler Meeresforschungen 12: 85-109.

Gerlach S.A. 1962. Freilebende Meeresnematoden von den Malediven. Kieler Meeresforschungen 18: 81-108.

Holovachov O. 2014. 7.16 Order Plectida Gadea, 1973. In: Schmidt-Rhaesa A. (ed.) Handbook of Zoology. Gastrotricha, Cycloneuralia and Gnatifera. Volume 2: Nematoda: 487-536. de Gruyter, Berlin.

Holovachov O., Fadeeva N., Tandingan De Ley I., Mundo-Ocampo M., Gingold R. \& De Ley P. 2012. Revision and phylogeny of Tarvaia Allgén, 1934 (Nematoda: Tarvaiidae). Nematology 14: 677-708. https://doi.org/10.1163/156854112X627255

Holovachov O., Tandingan De Ley I., Mundo-Ocampo M., Gingold R. \& De Ley P. 2009. Nematodes from the Gulf of California. Part 3. Three new species of the genus Diplopeltoides Gerlach, 1962 (Nematoda: Diplopeltoididae) with overviews of the genera Diplopeltis Gerlach, 1962 and Diplopeltula Gerlach, 1950. Russian Journal of Nematology 17: 43-57.

Hunt D.J \& Palomares-Ruis E. 2012. General morphology and morphometrics of plant-parasitic nematodes. In: Manzanilla-López R.H. \& Marbán-Mendoza N. (eds) Practical Plant Nematology: 2564. Mundi-Prensa, Madrid.

Jensen P. 1978. Four nematoda Araeolaimida from Öresund, Denmark, with remarks on the oesophageal structure in Aegialoalaimus. Cahiers de Biologie marine 19: 221-231.

Jensen P. 1991. Nine new and less known nematode species from the deep-sea benthos of the Norwegian Sea. Hydrobiologia 222: 57-76. https://doi.org/10.1007/BF00017500

Leduc D. 2013. Mudwigglus gen. n. (Nematoda: Diplopeltidae) from the continental slope of New Zealand, with description of three new species and notes on their distribution. Zootaxa 3682: 351-370. https://doi.org/10.11646/zootaxa.3682.2.8

Leduc D. 2017. Four new nematode species (Araeolaimida: Comesomatidae, Diplopeltidae) from the New Zealand continental slope. Zootaxa 4237: 244-264. https://doi.org/10.11646/zootaxa.4237.2.2

Lorenzen S. 1981. Entwurf eines phylogenetischen Systems der freilebenden Nematoden. Veröffentlichungen des Instituts für Meeresforschung in Bremerhaven, Supplement 7: 1-472.

Seinhorst J.W. 1959. A rapid method for the transfer of nematodes from fixative to anhydrous glycerin. Nematologica 4: 67-69. https://doi.org/10.1163/187529259X00381

Tchesunov A.V. 1990. A critical analysis of the family Aegialoalaimidae (Nematoda, Chromadoria), trends in evolutionary development of marine nematode pharynx and a proposal of two new families. Zoologicheskii Zhurnal 69: 5-18.

Tchesunov A.V. 2006. Biology of marine nematodes. Moscow, KMK Scientific Press.

Timm R.W. 1961. The marine nematodes of the Bay of Bengal. Proceedings of the Pakistan Academy of Sciences 1: 1-88.

Vincx M. \& Gourbault N. 1992. Six new species of the genus Diplopeltula (Nematoda: Diplopeltidae) with remarks on the heterogeneity of the taxon. Hydrobiologia 230: 165-178.

https://doi.org/10.1007/BF00036563

Vitiello P. 1972. Sur quelques espèces de Diplopeltula (Nematoda, Araeolaimida). Vie et Milieu 21: 535-544. 
Manuscript received: 12 January 2017

Manuscript accepted: 28 April 2017

Published on: 23 November 2017

Topic editor: Rudy Jocqué

Desk editor: Natacha Beau

Printed versions of all papers are also deposited in the libraries of the institutes that are members of the EJT consortium: Muséum national d'Histoire naturelle, Paris, France; Botanic Garden Meise, Belgium; Royal Museum for Central Africa, Tervuren, Belgium; Natural History Museum, London, United Kingdom; Royal Belgian Institute of Natural Sciences, Brussels, Belgium; Natural History Museum of Denmark, Copenhagen, Denmark; Naturalis Biodiversity Center, Leiden, the Netherlands; Museo Nacional de Ciencias Naturales-CSIC, Madrid, Spain; Real Jardín Botánico de Madrid CSIC, Spain. 